Research article

\title{
The nutty world of hazel names - a critical taxonomic checklist of the genus Corylus (Betulaceae)
}

\author{
Norbert HOLSTEIN ${ }^{1, *}$, Sarah el TAMER ${ }^{2}$ \& Maximilian WEIGEND ${ }^{3}$ \\ 1,2,3 Nees Institut für Biodiversität der Pflanzen, Universität Bonn, \\ Bonn, Nordrhein-Westfalen, Germany. \\ *Corresponding author: holstein@uni-bonn.de \\ ${ }^{2}$ Email: $\underline{\text { saraheltamer@hotmail.com }}$ \\ ${ }^{3}$ Email: mweigend@uni-bonn.de
}

\begin{abstract}
Hazelnuts (Corylus L.) are the source of one of the globally most important nut crops. Despite their economic and cultural importance, taxonomic knowledge is poor, even the number of species is equivocal. Weak morphological differentiation, the inconsistent taxonomic treatment of horticultural selections and cultivars, and uncritical regional treatments generated a multitude of names. The situation is further complicated by an ancient history of use (at least 10400 years), trade (at least 4000 years) and domestication (at least 2000 years). Here, we present an annotated checklist of the taxa in the genus Corylus based on an extensive literature review, electronic database research, and visits to some European herbaria. Full citations are given for all names, typifications are provided for the majority of them. Cultivars are listed if described under the rules of the ICN. We designate lectotypes and neotypes for 28 names, and discuss the identity of enigmatic C. maxima Mill., a taxon not known from the wild.
\end{abstract}

Keywords. Herbarium digitization, taxon inventory, taxonomy, typification.

Holstein N., Tamer S. el \& Weigend M. 2018. The nutty world of hazel names - a critical taxonomic checklist of the genus Corylus L. (Betulaceae). European Journal of Taxonomy 409: 1-45. https://doi.org/10.5852/ejt.2018.409

\section{Introduction}

Species of the genus Corylus L. (Betulaceae Gray) are distributed in the Northern Hemisphere and grow as shrubs or trees. The genus is readily recognized by its characteristic fruits, with a large, oil-rich seed enclosed in a brown pericarp, which in turn is enveloped by a large, tubular or foliose involucre. The detailed morphology of the involucre, the shape and size of the nut, and the leaf indument are the most important morphological traits in species delimitation. Human use of hazelnuts has an ancient history across its distribution range, and dates back at least to 8400 years $\mathrm{BC}$ in western and central Europe (Holst 2010; Zohary et al. 2012; Antolín \& Jacomet 2015), North America (Abrams \& Nowacki 2008; Fine et al. 2013) and China (Keightley 1983; Liu \& Chen 2012). There is evidence that hazelnuts have been traded at least regionally as early as 4000 years ago (Fairbairn et al. 2014) and cultivation and domestication probably developed independently in the western and the eastern Mediterranean at least 2000 years ago (Pliny the Elder 77-79; Boccacci \& Botta 2009). Today, hazelnuts are one of the most important nut crops world-wide with more than 850000 tons produced in 2013 (FAOstat 2013), with 
most of the commercial production in Turkey. In spite of the economic importance, the taxonomy of Corylus is poorly understood and even the wild ancestors of the cultivars are still enigmatic. One of the most mysterious species in this context is C. maxima Mill. It has been variously reported as a wild species occurring in Lombardy (hence the name "lamberts nut") (Gesner in Cordus 1561: 249r) and in the Balkans (Bobrov 1936a; Săvulescu 1952; Tutin \& Walters 1993), yet this name is neither typified nor are unequivocal wild populations known. This is especially surprising because C. maxima is the species name employed for a wide range of commercial cultivars and is commonly regarded as (one of the) progenitor(s) of the cultivated hazelnut in Europe (Kosenko 2002). Also, in the context of wild crop relatives, for example, in attempts to use resistant strains for breeding against the various diseases, such as eastern filbert blight or hazel dieback "moria", a clear understanding of the systematics of Corylus would be highly desirable.

The delimitation of Corylus is undisputed due to the easily recognizable nut. Corylus is sister to the other genera of the Coryloideae: Carpinus L., Ostrya Scop., and Ostryopsis Decne. (Forest et al. 2005; Li 2008; Grimm \& Renner 2013). The infrageneric classification varies, however, depending on whether tree-like growth is regarded as an important character (Schneider 1916) or if involucre morphology is considered more important (Spach 1841; Candolle 1864; Bobrov 1936a; Li \& Cheng 1979). Undisputed, however, is the acceptance of the group of hazels with spiny bracts (C. ferox Wall., C. ferox var. tibetica (Batalin) Franch.) as C. sect. Acanthochlamys Spach (Spach 1841). Whitcher \& Wen (2001) place the remainder into a single second section, $C$. sect. Corylus, based on ITS data with three subsections: tree hazels (Colurnae C.K.Schneid.), hazels with tubular bracts (C. subsect. Siphonochlamys (Bobr.) P.C.Li), and Corylus (shrubs with leafy bracts). These relationships are also supported by crossing experiments: Erdoğan (1999) and Erdoğan \& Mehlenbacher (2000) found incompatibility or only unilateral compatibility especially between species of different subsections, while C. americana Walter and C. avellana L. (C. subsect. Corylus), and C. sieboldiana Blume, C. cornuta Marshall, and C. californica (A.DC.) Rose (C. subsect. Siphonochlamys) were found to be fully interfertile.

This study aims at clarifying the published names in the genus Corylus as another step towards a taxonomic re-evaluation of Betulaceae subfam. Coryloideae (Holstein \& Weigend 2016a, 2017). We aim at a complete listing of the published species and infraspecific names under the provisions of the ICN (McNeill et al. 2012) for Corylus, providing typifications where required and where possible. Since many cultivars have been described as biological taxa, we also list cultivars. However, this paper does not intend to list all cultivars or to evaluate which cultivars are to be accepted. It intends to provide their correct names according to the rules of the ICN or ICNCP (Brickell et al. 2009) respectively if the cultivars are to be accepted.

\section{Material and methods}

We adopted the list of names from the World Checklist of Selected Plant Families (WCSP 2016) and supplemented it with overlooked names by an extensive internet search and names given on herbarium specimens. The acceptance status was compared with those on the World Checklist and Bibliography of Fagales (Govaerts \& Frodin 1998) and the relevant floristic treatments: Flora of China (Li \& Skvortsov 1999), Flora Sichuanica (Editorial Board of the Flora Sichuanica 2012), Flora Europaea (Tutin \& Walters 1993), Flora of Japan (Ohwi 1965), Flora of North America (Furlow 1997), the Flora of the USSR (Bobrov 1936a), and the last genus-wide revision (Bobrov 1936b). For further names, we surveyed The Plant List (http://www.theplantlist.org), IPNI (http://www.ipni.org), Tropicos (http://www.tropicos.org), and IFPNI (http://fossilplants.info/). Synonyms are listed here according to WCSP (2016), or if not listed there, then according to the species the taxon is currently assigned to. We also list cultivar names if published under the provisions of the ICN (McNeill et al. 2012). The names of Dochnahl (1860) applicable to Corylus are ignored, as the work was added to the opera utique oppressa (cf. Greuter \& Holstein 2016; Holstein \& Greuter 2016; Wilson 2017). 
For typification, the first author searched the following herbaria for type specimens in situ: $\mathrm{B}, \mathrm{BM}$, BR, E, GOET, K, LIV, M, MANCH, MSB, W, and WU. Additional collections were obtained via personal communication (G, LE, MT, NEU, TBI) or in silico: Chinese Virtual Herbarium $(\mathrm{CVH}$, http://www.cvh.org.cn/), NHN Naturalis (L, U, WAG), and homepages of the following herbaria: A, BLH, GH, LE, LINN, MO, MW, NY, P, PH, UC, and US.

\title{
Results
}

Currently, 22 taxa in 17 species are accepted in Corylus (WCSP 2016), and 10 legitimate basionyms can be accepted for cultivars. Overall, we located 144 legitimate basionyms, with 85 synonyms for C. avellana var. avellana alone. Sixty-one of these were described by a single author, Henriksson (1915, 1918, 1923, 1927, 1930, 1931), who meticulously described all differences he found in Scandinavian collections of $C$. avellana. In addition to the legitimate basionyms, 17 illegitimate and 40 invalid names were found for the different Corylus species. Two names of arguably new taxa, C. spiculata C.C.Yang and $C$. heteromorpha C.C.Yang (or C. heleromorpha) were found on Chinese herbarium specimens, but no publication was found.

\section{Checklist of Corylus}

\author{
Order Fagales Engl. \\ Family Betulaceae Gray \\ Subfamily Coryloideae Hook.f. \\ Tribe Coryleae A.DC.
}

\section{Corylus L.}

Species Plantarum: 998 (Linnaeus 1753). - C. sect. Avellana Spach, Annales des Sciences naturelles, seconde série - Botanique 16: 101 (Spach 1841) nom. inval. (Art. 22.2, McNeill et al. 2012). C. subsect. Euavellanae C.K.Schneid., Plantae Wilsonianae 2: 447 (Sargent 1916) nom. inval. (Art. 21.3, McNeill et al. 2012). - C. sect. Diphyllon Bobrov, Sovietskaia Botanica 1936 (1): 28 (Bobrov 1936b) nom. inval. - C. ser. Lacerae Bobrov, Sovietskaia Botanica 1936 (1): 28 (Bobrov 1936b) nom. inval. - Type species: C. avellana L., lectotypified by Britton \& Brown (1913: 607).

C. sect. Acanthochlamys Spach, Annales des Sciences naturelles, seconde série - Botanique 16: 108 (Spach 1841). - C. subg. Acanthochlamys (Spach) Bobr., Sovietskaia Botanica 1936 (1): 27 (Bobrov 1936b). - C. subsect. Acanthochlamys (Spach) C.J.Wang, Flora Yunnanica 5: 173 (Academia Sinica Kunming Institute of Botany 1991) nom. inval. [no basionym reference]. - Type species: C. ferox Wall.

C. sect. Tuboavellana Spach, Annales des Sciences naturelles, seconde série-Botanique 16: 106 (Spach 1841). ["Tubo-Avellana"]. - Type species: not designated (the section included C. tubulosa Willd. and C. rostrata Aiton).

C. sect. Avellana subsect. Colurnae C.K.Schneid., Plantae Wilsonianae 2: 447 (Sargent 1916). - Type species: C. colurna $\mathrm{L}$.

C. subg. Phyllochlamys Bobrov, Sovietskaia Botanica 1936 (1): 28 (Bobrov 1936b). - Type species: not designated.

C. subg. Phyllochlamys sect. Diphyllon ser. Incisae Bobrov, Sovietskaia Botanica 1936 (1): 29 (Bobrov 1936b). - C. subsect. Phyllochlamys (Bobr.) C.J.Wang, Flora Yunnanica 5: 174 (Academia Sinica Kunming Institute of Botany 1991) nom. inval. (no basionym reference). - Type: not designated (the series included C. americana Walter, C. heterophylla Fisch. ex Trautv. and C. potaninii Bobrov). 
C. subg. Phyllochlamys sect. Monophyllon Bobrov, Sovietskaia Botanica 1936 (1): 32 (Bobrov 1936b). - Type: not designated (the section included C. colchica Albov, C. maxima Mill. and C. pontica K.Koch).

C. subg. Siphonochlamys Bobrov, Sovietskaia Botanica 1936 (1): 32 (Bobrov 1936b). - C. sect. Siphonochlamys (Bobr.) C.J.Wang, Flora Yunnanica 5: 174 (Academia Sinica Kunming Institute of Botany 1991) nom. inval. (no basionym reference). - C. sect. Siphonochlamys (Bobr.) C.C.Yang, Flora Sichuanica 21: 7 (Editorial Board of the Flora Sichuanica 2012). - C. subsect. Siphonochlamys (Bobr.) P.C.Li, Flora Republicae Popularis Sinicae 21: 51 (Li \& Cheng 1979). - Type species: not designated (the subgenus included C. brevituba Kom., C. californica (A.DC.) Rose, C. chinensis Franch., C. cornuta Marshall, C. fargesii (Franch.) C.K.Schneid., C. mandshurica Maxim., C. papyracea Hickel, C. sieboldiana Blume and C. yunnanensis (Franch.) A.Camus).

\section{Corylus americana Walter}

Flora Caroliniana: 236 (Walter 1788). - Type: USA, Georgia, Taccoa, Herbersham Co., 1200 ft., 17-20 Aug. 1895, J.K. Small s.n. (neo-, designated by Ward (2007: 1099) and here corrected: A00247927!; isoneo-: NY01185413!). - Note: Walter's Herbarium was in the hands of John Fraser's family and later sold to BM (Stafleu \& Cowan 1976-1988), but apparently lost. Ward therefore designated the neotype at the Gray Herbarium (GH), but the specimen is actually part of the collection of Arnold Arboretum (A). As both collections are housed in the same building, we correct Ward's minor mistake. There is no type locality mentioned in the protologue. The name is recognized as a species in the Flora of North America (Furlow 1997) and World Checklist and Bibliography of Fagales (Govaerts \& Frodin 1998).

C. humilis Willd., Enumeratio Plantarum Horti Regii Berolinensis: 983 (Willdenow 1809). - C. nana Bosc, Encyclopédie Méthodique, Agriculture 7: 597 (Tessier et al. 1821) nom. nud. (though it would also be illegitimate due to C. nana Tourrette \& Rozier). - C. pumila Spach, Annales des Sciences naturelles, seconde série - Botanique 16: 104 (Spach 1841) nom. nud. - C. americana [unranked] humilis (Willd.) Dippel, Handbuch der Laubholzkunde 2: 132 (Dippel 1891) ["1892"]. - C. americana f. humilis (Willd.) Schelle, Handbuch der Laubholzbenennung: 50 (Beissner et al. 1903). - Type: USA, "Noveboraco" (New York), s. coll. in Herb. C.L. von Willdenow s.n. (lecto-, designated here: B-W 17705!). - Note: Willdenow cited a description by Wangenheim (1787: 88), in which Wangenheim mentioned that the American Hazel was growing rather smallish (8 to 10 feet). Initially, Willdenow (1805: 471) provided the phrase name Corylus americana humilis, but without recognizing it as a distinct taxon. In 1809, Willdenow recognized it as a separate species, C. humilis, which he considered as close to C. americana, but with leaves like those of $C$. avellana. Corylus pumila mentioned by Spach (1841) is supposed to be based on Willdenow. However, to our knowledge there is no Willdenow name "Corylus pumila". Possibly, Spach's epithet was supposed to be a nom. nov. Another name was published by Bosc in the agricultural vol. 7 of Lamarck's Encyclopédie Méthodique (Tessier et al. 1821). There, Bosc mentioned a C. nana from Eastern North America, supposedly based on Willdenow. More likely, the name was confused, because Willdenow called his dwarf hazel C. humilis, besides that " $C$. nana" had been published before for a low-growing C. colurna (La Tourrette \& Rozier 1787). The lectotype is taken from Willdenow's own collection. Additional original material might exist in Wangenheim's collection, which was at least partly handed over to Schreber (Zuccarini 1833), and might be housed in M.

C. americana var. missouriensis A.DC., Prodromus Systematis Naturalis Regni Vegetabilis 16 (2): 132 (Candolle 1864). - C. americana f. missouriensis (A.DC.) Fernald, Rhodora 34: 96 (Fernald 1932). - Type: USA, Missouri, Saint-Louis, N. Riehl 91 (holo-: G00418162!; iso-: BR0000013516888!, MO1181611!).

C. serotina G.Kirchn., Arboretum Muscaviense: 672 (Petzold \& Kirchner 1864). - Type: not localized, from cultivation from Königliche Landesbaumschule Sanssouci [Potsdam, Germany]. - Note: 
Petzold was in contact to Schlechtendal in HAL (Stafleu \& Cowan 1976-1988), possibly original material may be found there.

C. virginiana hort., Die Haselnuss: 90 (Goeschke 1887) nom. nud. - C. virginiana hort. ex Dippel, Handbuch der Laubholzkunde 2: 132 (Dippel 1891) [“1892"] nom. inval. pro syn.

C. calyculata Dippel, Handbuch der Laubholzkunde 2: 132 (Dippel 1891) ["1892"]. - C. americana [unranked] calyculata (Dippel) Schelle, Handbuch der Laubholzbenennung: 50 (Beissner et al. 1903). - C. americana var. calyculata (Dippel) H.J.P.Winkl., Das Pflanzenreich IV 61 (Heft 19): 48 (Winkler 1904). - Original citation: "Diese von Göschke, dem wir unsere Pflanze verdanken (...)" - Type: not localized [from cultivation by Goeschke]. - Note: this is supposed to be a weakly growing plant in contrast to the larger C. americana, very likely the same that Willdenow described as $C$. humilis Willd.

C. americana var. altior Farw., Report of the Michigan Academy of Science 17: 168 (Farwell 1915).Type: USA, Michigan, Algonac, 7 Jul. 1912, O.A. Farwell 2822 (syn-: BLH0000405); ibid., 8 Sep. 1912, O.A. Farwell 3154 (syn-: BLH0000408, BLH0000409, BLH0000410); Canada, Ontario, Stoney Creek, 27 Oct. 1912, O.A. Farwell 3266 (syn-: BLH0000406, BLH0000411).

C. americana var. indehiscens E.J.Palmer \& Steyerm., Annals of the Missouri Botanical Garden 22: 516 (Palmer \& Steyermark 1935). - Type: USA, Missouri, Greenwood, Jackson Co., 5 Sep. 1924, B.F. Bush 10332 (holo-: A00033774!; iso-: K!, MIN1000722). - Additional type material: ibid., E.J. Palmer 26035 (para-: A); ibid., Arkansas, Martinsville, Faulkner Co., 13 Oct. 1924, E.J. Palmer 26537 (para-: A); ibid., Hot Springs, Garland Co., 11 Oct. 1925, E.J. Palmer 29160 (para-: A); ibid., North Carolina, 19 Sep. 1897, Biltmore Herb. 1244b (isopara-: WU!).

\section{Corylus avellana L.}

Species Plantarum: 998 (Linnaeus 1753). - Original citation: "Habitat in Europae sepibus". - Type: "Avellana nux sylvestris" (lecto-, designated by Sell (Jarvis et al. 1993: 38): Fuchs (1542: 397, 398) [icon]). - Note: The lectotypification by Browicz (1972: 97) in Rechinger's Flora Iranica (LINN 1132.1) is superseded because: 1) the chosen specimen featured the note "byzantinus", which Sell interpreted to be in conflict with the protologue, and 2) it may be post 1753 material. However, it would have been a better match for interpretation, because it actually shows the one character Linnaeus uses to separate the species from C. colurna, this being the ovate, obtuse stipules. The lectotype chosen by Sell, on the other hand does not show stipules, but instead a short cupula, a character that is accepted as typical for the wild C. avellana. As the type of the genus, C. avellana $\mathrm{L}$. is to be accepted as long as the genus itself is accepted.

\section{2a. Corylus avellana L. var. avellana}

C. avellana var. sylvestris Ehrh., Hannoverisches Magazin 18: 234 (Ehrhart 1780) nom. nud.

C. avellana var. grandis Aiton, Hortus Kewensis 3: 363 (Aiton 1789). - C. grandis (Aiton) Nois., Manuel Complet du Jardinier, Maraicher, Pépiniériste, Botaniste, Fleuriste et Paysagiste 2: 464 (Noisette 1825) (recombination, Art. 41.4, McNeill et al. 2012). - C. avellana var. cylindricochlamys Spach, Annales des Sciences naturelles, seconde série - Botanique 16: 106 (Spach 1841) nom. illegit. superfl. - Original citation: only a reference to "Corylus sativa fructu rotundo maximo" (Bauhin 1623: 418), which does not contain figures. - Type: not localized (no original specimen found in BM or K). - Note: Bauhin only cited "Avellana urbana rotunda circa Lugdunum, Ges.hor." being an abbreviation for "Gesnerus in libro de hortis Germaniae and Avellana major Lugdunensis, Cam." (Cordus 1561: 249r; Camerarius the Younger 1588: 24). Both citations lack figures, but describe a large and round fruited hazel from the area of Savoy, France and Lausanne, Switzerland (Gesner in Cordus 1561: 249r). Aiton published the name grandis for the "cob nut", apparently a popular group of cultivars with large round nuts back then and still widely cultivated, for example, 
in southern Italy and northern Spain. The form is morphologically close to the extant cultivar C. avellana 'Barcelona'. Loudon (1838: 2018) even synonymized C. avellana var. grandis under his C. avellana var. barcelonensis, creating a superfluous name. Thus, C. avellana var. grandis would be the botanical name for the cultivated forms of Corylus with a large, round nut. They appear to have been in cultivation in Italy, France and Spain since ancient times and likely represent large-fruited selections of the wild $C$. avellana. All names cited under $C$. avellana var. cylindricochlamys Spach ultimately refer to Bauhin's Corylus sativa fructu rotundo maximo (Bauhin 1623), later published as C. avellana var. grandis Aiton. Therefore, Spach's name is a homotypic synonym.

C. avellana var. sylvestris Aiton, Hortus Kewensis 3: 363 (Aiton 1789) nom. inval. - C. sylvestris (Aiton) Salisb., Prodromus Stirpium in Horto ad Chapel Allerton Vigentium: 392 (Salisbury 1796) nom. inval. - Note: the citation of the name C. avellana var. sylvestris includes the type of C. avellana, and also Salisbury cites C. avellana.

C. avellana var. striata Willd., Species Plantarum ed. 44 (1): 470 (Willdenow 1805). - C. avellana var. striata Risso, Histoire Naturelle des Principales Productions de l'Europe Méridionale et particulièrement de Celles des Environs de Nice et des Alpes Maritimes 2: 332 (Risso 1826) nom. illegit. (later homonym; Art. 53.4, McNeill et al. 2012). - Type: not localized. - Note: Risso most likely used Willdenow's name without citing him.

C. avellana var. ovata Willd., Species Plantarum ed. 44 (1): 470 (Willdenow 1805). - C. avellana var. ovata Risso, Histoire Naturelle des Principales Productions de l'Europe Méridionale et particulièrement de Celles des Environs de Nice et des Alpes Maritimes 2: 331 (Risso 1826) nom. illegit. (later homonym). - C. ovata Lam. ex Steud., Nomenclator Botanicus ed. 2 1: 424 (Steudel 1840) nom. inval. pro syn. - Type: iconotype, Lamarck (1796-1797: pl. 780n). - Note: Steudel's name is often cited as Lam. ex Steud., but the author of the name is Willdenow. Willdenow described this variety based on a drawing in Lamarck's Illustration des genres, which is more commonly cited as Tableau encyclopédique et méthodique (Stafleu \& Cowan 1976-1988). Steudel most likely misinterpreted Willdenow's reference to Lamarck's figure and attributed the name to Lamarck. As Steudel cited the name in synonymy, it is invalid anyway.

C. avellana var. maxima Audib., Catalogue des Arbres, Arbrisseaux, Arbustes, et Plantes: 15 (Audibert 1817). -Type: not localized (cult.). - Note: the term "maxima" is misapplied many times. In his C. maxima Mill., Miller (1768) explicitly refers to a Corylus with oblong fruits, whereas the fruits of C. avellana var. maxima Audib. are large and rounded, matching the morphology of C. avellana var. grandis. However, both names share long bracts that surpass the fruit, resulting in a similar external appearance.

C. avellana var. racemosa Risso, Histoire Naturelle des Principales Productions de l'Europe Méridionale et particulièrement de Celles des Environs de Nice et des Alpes Maritimes 2: 331 (Risso 1826). Type: not localized.

C. avellana var. crispa Loudon, Encyclopedia of Plants: 792 (Loudon 1829). - Type: not localized. Note: Loudon mentions C. avellana var. crispa briefly in the list (Loudon 1829) explaining that it is frizzled (most likely the bracts) in contrast to the other hazels. The diagnosis is short, not an automatic translation of the epithet and distinguishing, and therefore meeting the diagnostic criterion as set in Art. 38.2 (McNeill et al. 2012). There is a contemporary description without a Latin name by Lindley (1829, pl. 70), mentioning that this cultivar originated in a garden at Hoveton, near Norwich (England). Loudon, however, cited Lindley only in his Arboretum et Fruticetum Britannicum (Loudon 1838: 2018). The fruit is characterized by an elliptical nut enclosed in a flaring, laciniate involucre about twice its length (Loudon 1838, fig. 1943).

C. avellana var. ardua Poit. \& Turpin, Traité des Arbres Fruitiers 6: 46 (Poiteau \& Turpin 1835). Type: not localized (from wild collection from Normandy, France). - Note: Poiteau \& Turpin (1835) described this taxon, but they were not clear about its rank. Although the name in the title points to the rank of a species, being in the same style as it is done for C. avellana, they wrote in the first sentence that this is supposed to be a variety. We hence follow this designation. In a later publication 
(Poiteau 1846: 214), they added the information that this taxon was first cultivated by Hericard Ferrand in rue Sainte-Catherine, Paris, in 1812.

C. avellana var. microphylla Lej., Compendium Florae Belgicae 3: 256 (Lejeune \& Courtois 1836). - Original citation: "in Ardenna." - Type: [Belgium, Région wallonne, Liège] À Monganbroux [Mangombroux, today a quarter in Verviers], 1832, A.L.S. Lejeune s.n. (lecto-, designated here: $\mathrm{BR}$ !).

C. avellana var. barcelonensis Loudon, Arboretum et Fruticetum Britannicum 3: 2018 (Loudon 1838) nom. illegit. superfl. (superfluous as Loudon cited C. avellana var. grandis Aiton).

C. avellana var. lambertii Loudon, Arboretum et Fruticetum Britannicum 3: 2018 (Loudon 1838). Type: not localized. - Note: this name is used for a cultivated variety from Loddiges garden catalogue (Loddiges 1836). However, in contrast to the Lambert's nut in the sense of C. maxima (where the name may be derived from Lombardy), this name for a cultivar is supposedly derived from a plant breeder named Lambert, most likely for what is today widely called "Kentish Cob" (Bunyard 1920). It has an oblong nut with a rather rounded apex and the involucre barely exceeding the nut in length.

C. avellana var. pumila Loudon, Arboretum et Fruticetum Britannicum 3: 2017 (Loudon 1838). C. pumila Lodd., Catalogue of Plants ed. 16: [page unknown] (Loddiges 1836) nom. nud. - Type: not localized.

C. avellana var. glandulosa Godet, Mémoires de la Société des sciences naturelles de Neuchâtel 2: 15 ["Dicotyledones"], 3 [“Additions et corrections en 1838"] (Godet 1839). - C. glandulosa (Godet) Shuttleworth ex Godet, Flore du Jura: 639 (Godet 1853). - Original citation: "Au dessus de Nods et de Lignières, au pied de Chasseral." - Type: Switzerland, in dumetis ad pedem M. Chasseral prope Lignières, et versus Nods, et in vall. Lignières frequens, 5 Jul. 1835, R.J. Shuttleworth s.n. (lecto-, designated here: NEU! [acc. no. 204561]). - Original material: Switzerland, in dumetis ad pedem M. Chasseral versus nods et in Vall. Lignières ubique, 6 Jul. 1835, R.J. Shuttleworth s.n. (BM!). - Note: initially, Godet's name lacks a description that he adds in "Additions et corrections en 1838" lateron (submitted on 31 Dec. 1838), so only then the publication can be regarded as valid. The name C. glandulosa also appears on a specimen collected by E. Perrier in P (P06810712) and is referred to be by Ehrhart, however, the present authors are unaware of any Ehrhart publication of this name.

C. arborea hort. ex Steud., Nomenclator Botanicus ed. 2 1: 424 (Steudel 1840) nom. inval. pro syn.

C. avellana var. brachychlamys Spach, Annales des Sciences naturelles, seconde série - Botanique 16: 106 (Spach 1841) nom. illegit. superfl. - Note: Spach cited C. avellana var. ovata Willd. and a "Corylus avellana var. sylvestris", which is most likely the name of Aiton, therefore this name is superfluous.

C. avellana var. macrochlamys Spach, Annales des Sciences naturelles, seconde série - Botanique 16: 106 (Spach 1841) nom. illegit. superfl. - Note: Spach cited C. avellana var. glomerata hort. (Kew), which was published by Aiton, but also C. avellana var. maxima Audib., which is regarded as synonymous to C. avellana var. grandis.

C. avellana var. schizochlamys Spach, Annales des Sciences naturelles, seconde série - Botanique 16: 106 (Spach 1841). - Original citation: "Commune dans les bois aux environs de Paris." - Type: not localized. - Note: based on the name chosen, Spach referred to the very common form of C. avellana with deeply dissected involucre.

C. avellana var. sphaerocarpa Rchb., Icones Florae Germanicae et Helveticae 12: 5, pl. DXXXVIII: 1302 (Reichenbach 1850). - Type: not localized (the iconotype would be in loc. cit.). - Note: Reichenbach mentioned that this variety was intermediate between C. avellana s.str. and "C. grandis" (C. avellana var. grandis Aiton).

C. spicata G.Kirchn., Arboretum Muscaviense: 673 (Petzold \& Kirchner 1864). - Type: not localized (cult. in the State nursery near Sanssouci, Potsdam, Germany).

C. avellana var. latifolia hort. ex A.DC., Prodromus Systematis Naturalis Regni Vegetabilis 16 (2): 131 (Candolle 1864). - C. filicifolia hort. ex A.DC., Prodromus Systematis Naturalis Regni Vegetabilis 
16 (2): 131 (Candolle 1864) nom. inval. pro syn. - Type: not localized. - Note: De Candolle mentioned a large-leaved variety latifolia that has been in gardens as "latifolia" and "filicifolia".

C. hispanica K.Koch, Die Deutschen Obstgehölze: 607 (Koch 1867). - Type: not localized (from cultivation). - Note: Koch discussed the early hazel names and mentioned that the taxon behind his C. hispanica was already mentioned by Gesner (Cordus 1561: 249r). It is therefore evident that this is yet another name for what had already been described as C. avellana var. grandis Aiton.

C. avellana var. mediopurpurea Späth, Baumschule. Haupt-Preis-Verzeichniss, 1883 57: 2 (Späth 1883). - Type: not localized. - Note: the present authors did not have the protologue at hand for verification of the validity. Späth (1885) described the cultivar as having a red marking in the leaf center.

C. avellana var. gloiotricha Beck, Fl. Nieder-Oesterreich 1: 267 (Beck von Mannagetta 1890). - Original citation: "In Voralpen." - Type: not localized.

C. avellana var. glaucescens Borbás, C. Baenitz Herbarium Europaeum no. 8333 (1895-1896) nom. nud. in sched. - Associate material: Hungaria centr., Budae-Pestini, in declivibus nemoris Zugliget, Aug. 1895, V. de Borbás s.n. (M!, P06809854!, P06809903!, P06810667!, P06810668!, WU!). Note: to the present authors' knowledge, this is an unpublished name for a hazel with a glaucous lower leaf lamina.

C. avellana var. zimmermannii Hahne, Mitteilungen der Deutschen dendrologischen Gesellschaft 12: 127 (Beissner 1903). - Original citation: "Zu Ende September 1903 machte mich Herr Lehrer E. Zimmermann in Schwelm [Northrhine-Westphalia, Germany; ...] eine alte Hecke im Süden der Stadt, zu führen." - Type: not localized (if in BONN, then destroyed). - Note: this is a formal description for a mutation in which the leaf bases are connected to form a cone. Hahne lived in Bonn-Poppelsdorf, so there may have been a specimen at BONN, but the herbarium was largely destroyed in 1944 and there is no extant material. Also, the author's intention to graft the mutation for further study was apparently not followed. Krüssmann (1960: 351) lists this name as a cultivar, but mixing up the birth place and year of E. Zimmermann with the original collection data in his reference. As an aberrant individual, it does not deserve taxonomic recognition.

C. avellana f. peltata Buser, Société pour l'Étude de la flore franco-helvétique no. 1544 (Buser 1904) in sched. - Type: Switzerland, Geneva, haies à Lancy, 30 Sep. 1903, R. Buser s.n. (syn-: P05591949!, P06809904!, P06810696!). - Note: the name was also published in the Bulletin of the Société pour l'Étude de la flore franco-helvétique, which is a short list in the Bulletin de l'Herbier Boissier (Camus et al. 1905: 974, 976).

C. avellana f. grandifolia Zapał., Conspectus Florae Galiciae Criticus 2: 10 (Zapałowicz 1908). Original citation: "Ojców (Rehman)." - Type: not localized (likely in KRAM, cf. Stafleu \& Cowan 1976-1988).

C. avellana var. acuminata Henriksson, Botaniska Notiser 1915 (5): 247 (Henriksson 1915). - Type: Sweden, Dalia, paroecia Gunnarsnäs ad Östevatten, J. Henriksson s.n. (holo-: not localized).

C. avellana var. acutiuscula Henriksson, Botaniska Notiser 1915 (5): 244 (Henriksson 1915). - Type: Sweden, in Helsingia, paroecia Segerstad ad Elftorp, C. Strandberg s.n. (holo-: not localized).

C. avellana var. amblyocarpa Henriksson, Botaniska Notiser 1915 (5): 244 (Henriksson 1915). - Type: Sweden, Dalia, paroecia Holm ad Hålsungebyn, P.J. Örtengren s.n. (syn-: not localized); Sweden, Dalia, paroecia Gunnarsväs ad Mörtviken, J. Henriksson s.n. (syn-: not localized).

C. avellana var. apiculata Henriksson, Botaniska Notiser 1915 (5): 241 (Henriksson 1915). - Type: Sweden, Helsingia, paroecia Segerstad ad Elftorp, C. Strandberg s.n. (syn-: not localized); Sweden, Dalia, paroecia Holm ad Hålsungebyn, P.J. Örtengren s.n. (syn-: not localized).

C. avellana var. arcuata Henriksson, Botaniska Notiser 1915 (5): 239 (Henriksson 1915). - Type: Sweden, Dalia, paroecia Gunnarsväs ad Hällan, Backerud et Östevatten, J. Henriksson s.n. (syn-: not localized); Sweden, Dalia, paroecia Holm ad Hålsungebyn, P.J. Örtengren s.n. (syn-: not localized).

C. avellana var. cervispina Henriksson, Botaniska Notiser 1915 (5): 244 (Henriksson 1915). - Type: Sweden, in Oelandia, paroecia Bröttorp et Hålsungebyn, P.J. Örtengren s.n. (holo-: not localized). 
C. avellana var. compressa Henriksson, Botaniska Notiser 1915 (5): 241 (Henriksson 1915). - Type: Sweden, Dalia, paroecia Gunnarsnäs, ad Mörtviken, J. Henriksson s.n. (syn-: not localized); Sweden, Dalia, paroecia Ertemark ad Bengtsfors, J. Henriksson s.n. (syn-: not localized).

C. avellana var. cryptomeria Henriksson, Botaniska Notiser 1915 (5): 241 (Henriksson 1915). - Type: Sweden, Dalia, paroecia Holm ad Bröttorp, P.J. Örtengren s.n. (syn-: not localized); Sweden, Dalia, paroecia Ertemark ad Bengtsfors, 1 Aug. 1914, J. Henriksson s.n. (syn-: not localized; isosyn-: LD1780253); Sweden, Dalia, paroecia Gunnarsnäs ad Hjulsängen et Östevatten, paroecia Ör ad Långeerud, J. Henriksson s.n. (syn-: not localized).

C. avellana var. distans Henriksson, Botaniska Notiser 1915 (5): 239 (Henriksson 1915). - Type: Sweden, Dalia, paroecia Gunnarsnäs ad Backerud, 160 m a.s.1., 16 Sep. 1915, J. Henriksson s.n. (syn-: not localized; isosyn-: LD1798219); Sweden, in Oelandia, paroecia Vickleby ad Vicklevy, J. Ekström s.n. (syn-: not localized).

C. avellana var. ellipsoidea Henriksson, Botaniska Notiser 1915 (5): 246 (Henriksson 1915). - Type: Sweden, Dalia, paroecia Ertemark ad Bengtsfors, J. Henriksson s.n. (syn-: not localized); Sweden, Dalia, paroecia Ertemark ad Huvudgingen, 1 Aug. 1914, J. Henriksson s.n. (syn-: not localized; isosyn-: LD1793482).

C. avellana var. elongata Henriksson, Botaniska Notiser 1915 (5): 246 (Henriksson 1915). - Type: Sweden, in Smolandia, paroecia Femsjö ad Olastorp, H. Persson s.n. (syn-: not localized); Sweden, Dalia, paroecia Holm ad Bröttorp, P.J. Örtengren s.n. (syn-: not localized).

C. avellana var. fusiformis Henriksson, Botaniska Notiser 1915 (5): 246 (Henriksson 1915). - Type: Sweden, in Oelandia, paroecia Vickleby ad Vickleby, J. Ekström s.n. (syn-: not localized); Sweden, Dalia, paroecia Holm ad Bröttorp, P.J. Örtengren s.n. (syn-: not localized); Sweden, Dalia, paroecia Gunnarsnäs ad Hjulsängen, J. Henriksson s.n. (syn-: not localized).

C. avellana var. gibbosa Henriksson, Botaniska Notiser 1915 (5): 245 (Henriksson 1915). - Type: Sweden, in Smolandia, paroecia Femsjö ad Olastorp, H. Persson s.n. (syn-: not localized); Sweden, Dalia, paroecia Holm ad Hålsungebyn, P.J. Örtengren s.n. syn-: not localized); Sweden, Dalia, paroecia Ärtemark ad Bengtsfors et Huvudgingen, 1 Aug. 1914, J. Henriksson s.n. (syn-: not localized; isosyn-: LD1793418).

C. avellana var. glabrata Henriksson, Botaniska Notiser 1915 (5): 246 (Henriksson 1915). - Type: Sweden, Dalia, paroecia Holm ad Hålsungebyn, P.J. Örtengren s.n. (holo-: not localized).

C. avellana var. integra Henriksson, Botaniska Notiser 1915 (5): 241 (Henriksson 1915). - Type: Sweden, in Smolandia, paroecia Femsjö ad Olastorp, H. Persson s.n. (syn-: not localized); Sweden, Oelandia, paroecia Vickleby as Vickleby, J. Ekström s.n. (syn-: not localized).

C. avellana var. involucrata Henriksson, Botaniska Notiser 1915 (5): 245 (Henriksson 1915). - Type: Sweden, in Oelandia, paroecia Böda ad Böda, O. Carlsson s.n. (syn-: not localized); Sweden, Dalia, paroecia Holm ad Hålsungebyn, P.J. Örtengren s.n. (syn-: not localized).

C. avellana var. lacerata Henriksson, Botaniska Notiser 1915 (5): 244 (Henriksson 1915). - Type: Sweden, in Smolandia, paroecia Femsjö ad Olstorp, H. Persson s.n. (syn-: not localized); Sweden, Bahusia ad Rödbo prope oppidum Kungelv, K. Gustafson s.n. (syn-: not localized); Sweden, Dalia, paroecia Holm ad Bröttorp, P.J. Örtengren s.n. (syn-: not localized); Sweden, Dalia, paroecia Gunnarsnäs, ad Stakelund, J. Henriksson s.n. (syn-: not localized).

C. avellana var. lata Henriksson, Botaniska Notiser 1915 (5): 240 (Henriksson 1915). - Type: Sweden, in Gotlandia, paroecia Hejde, S.J. Stengård s.n. (syn-: not localized); Sweden, Helsingia, paroecia Segerstad ad Elftorp, C. Strandberg s.n. (syn-: Not localized); Sweden, Dalia, paroecia Gunnarsnäs as Östevatten, J. Henriksson s.n. (syn-: not localized).

C. avellana var. limbata Henriksson, Botaniska Notiser 1915 (5): 240 (Henriksson 1915). - Type: Sweden, Dalia, paroecia Gunnarsnäs, ad Mörtviken, 120 m a.s.1., 14 Sep. 1915, J. Henriksson s.n. (syn-: not localized; isosyn-: BR!, LD1797982, PH00006756!); Sweden, Dalia, paroecia Gunnarsnäs ad Backerud, Hjulsängen, Östevatten, J. Henriksson s.n. (syn-: not localized); Sweden, in Oelandia, par Vickleby as Vickleby, J. Ekström s.n. (syn-: not localized); Sweden, Bahusia, paroecia Ryr ad 
Heljebol, J. Henriksson s.n. (syn-: not localized); Sweden, Dalia, paroecia Ertemark ad Bengtsfors, $J$. Henriksson s.n. (syn-: not localized).

C. avellana var. menthoides Henriksson, Botaniska Notiser 1915 (5): 241 (Henriksson 1915). - Type: Sweden, in Oelandia, paroecia Böda ad Böda, O. Carlsson s.n. (holo-: not localized).

C. avellana var. oblonga G.Andersson, Botaniska Notiser 1915 (5): 245 (Henriksson 1915). - Type: Sweden, in Dalia, paroecia gunnarsnäs ad Östevatten et Hjulsängen, paroecia Ertemark ad Bengtsfors, $J$. Henriksson s.n. (syn-: not localized); Sweden, Smolandia, paroecia Femsjö ad Olastorp, $H$. Persson s.n. (syn-: not localized).

C. avellana var. obovata Henriksson, Botaniska Notiser 1915 (5): 245 (Henriksson 1915). - Type: Sweden, in Bahusia ad Rödbo prope Kungelv, K. Gustafson s.n. (syn-: not localized).

C. avellana var. pectinata Henriksson, Botaniska Notiser 1915 (5): 246 (Henriksson 1915). - Type: Sweden, Dalia, paroecia Gunnarsnäs, ad Östevatten, J. Henriksson s.n. (holo-: not localized).

C. avellana var. sulcata Henriksson, Botaniska Notiser 1915 (5): 241 (Henriksson 1915). - Type: Sweden, Dalia, paroecia Gunnarsnäs ad Östevatten, J. Henriksson s.n. (holo-: not localized).

C. avellana var. teretiuscula Henriksson, Botaniska Notiser 1915 (5): 239 (Henriksson 1915). - Type: Sweden, in Smolandia, paroecia Femsjö ad Olastorp, H. Persson s.n. (syn-: not localized); ibid., Oelandia, paroecia Vickleby ad Vickleby, J. Ekström s.n. (syn-: Not localized).

C. avellana var. truncata Henriksson, Botaniska Notiser 1915 (5): 247 (Henriksson 1915). - Type: Sweden, in Smolandia, paroecia Femsjö ad Olastorp, H. Persson s.n. (syn-: not localized); Sweden, Dalia, paroecia holm ad Bröttorp, P.J. Örtengren s.n. (syn-: not localized).

C. avellana var. turgida Henriksson, Botaniska Notiser 1915 (5): 240 (Henriksson 1915). - Type: Sweden, in Gotlandia, paroecia Hejde, S.J. Stengård s.n. (syn-: not localized); Sweden, Bahusia paroecia Ryr ad Heljebol, J. Henriksson s.n. (syn-: not localized); Sweden, Dalia, paroecia Gunnarsnäs, ad Östevatten, J. Henriksson s.n. (syn-: not localized).

C. avellana var. velutina Henriksson, Botaniska Notiser 1915 (5): 240 (Henriksson 1915). - Type: Sweden, Dalia, paroecia Holm ad Hålsungebyn, P.J. Örtengren s.n. (syn-: not localized); Sweden, paroecia Gunnarsnäs ad Östevatten, J. Henriksson s.n. (syn-: not localized [not LD1798302]).

C. avellana var. bulbosa Henriksson, Botaniska Notiser 1918 (6): 299 (Henriksson 1918). - Type: Denmark, Nærum railway station, E. Petersen s.n. (holo-: not localized).

C. avellana var. cuneata Henriksson, Botaniska Notiser 1918 (6): 299 (Henriksson 1918). - Type: Denmark, Nærum railway station, E. Petersen s.n. (holo-: not localized).

C. avellana var. cupulifera Henriksson, Botaniska Notiser 1918 (6): 299 (Henriksson 1918). - Type: Denmark, Nærum railway station, E. Petersen s.n. (holo-: not localized).

C. avellana var. orbicularia Henriksson, Botaniska Notiser 1918 (6): 299 (Henriksson 1918). - Type: Norway, southern Bergenhus amt, Störd [Stord], T. Bredal s.n. (holo-: not localized).

C. avellana var. praefracta Henriksson, Botaniska Notiser 1918 (6): 297 (Henriksson 1918). - Type: Sweden, Dalia, paroecia Gunnarsnäs in silva Hällan ad Mörtviken, J. Henriksson s.n. (holo-: not localized).

C. avellana var. annulata Henriksson, Botaniska Notiser 1923 (3): 283 (Henriksson 1923). - Type: Sweden, Dalia, paroecia Gunnarsnäs ad Östevatten, P.J. Örtengren s.n. (syn-: not localized); Sweden, Dalia, paroecia Gunnarsnäs ad Östevatten, J. Henriksson s.n. (syn-: not localized).

C. avellana var. attenuata Henriksson, Botaniska Notiser 1923 (3): 280 (Henriksson 1923). - Type: Sweden, Dalia, paroecia Gunnarsnäs, ad Mörtviken, J. Henriksson s.n. (syn-: not localized); Sweden, Bahusia, paroecia Tanum ad Rörvik haud procul a Grebbestad, V. Andersson s.n. (syn-: not localized).

C. avellana var. coelata Henriksson, Botaniska Notiser 1923 (3): 280 (Henriksson 1923). - Type: Sweden, Dalia, paroecia Holm ad Bröttorp, P.J. Örtengren s.n. (syn-: not localized); Sweden, Dalia, paroecia Gunnarsnäs ad sanatorium Kroppefjäll, J. Henriksson s.n. (syn-: not localized); Sweden, Ostrogothia, paroecia Landeryd ad Uvberget, P.H. Johansson s.n. (syn-: not localized). 
C. avellana var. complanata Henriksson, Botaniska Notiser 1923 (3): 281 (Henriksson 1923). - Type: Sweden, in Blekingia haud procul a Ronneby, E. Essén s.n. (syn-: not localized); Sweden, Dalia, paroecia Gunnarsnäs ad Östevatten, P.J. Örtengren s.n. (syn-: not localized); Sweden, Vestrogothia, paroecia Häggesled as Stinggården, G. Brandström s.n. (syn-: not localized); Sweden, Vestrogothia, paroecia Tun ad Gammaltorp, G. Brandström s.n. (syn-: not localized).

C. avellana var. extensa Henriksson, Botaniska Notiser 1923 (3): 281 (Henriksson 1923). - Type: Sweden, Dalia, paroecia Holm ad Bröttorp et Hålsungebyn, P.J. Örtengren s.n. (syn-: not localized); Sweden, Dalia, Gunnarsnäs ad Mörtviken et Östevatten, J. Henriksson s.n. (syn-: not localized); Sweden, Uplandia, Gustavsberg ad Farsta, P.H. Johansson s.n. (syn-: not localized); Sweden, Vestrogothia, paroecia Tun ad Gammaltorp, G. Brandström s.n. (syn-: not localized).

C. avellana var. glandulosa Henriksson, Botaniska Notiser 1923 (3): 281 (Henriksson 1923) nom. illegit. (later homonym). - Type: Sweden, in Blekingia prope Ronneby, E. Essén s.n. (syn-: not localized); Sweden, Dalia, paroecia Gunnarsnäs ad Mörtviken, J. Henriksson s.n. (syn-: not localized).

C. avellana var. ovalis Henriksson, Botaniska Notiser 1923 (3): 283 (Henriksson 1923). - Type: Sweden, in Blekingia, Bustorp ad Ronnyby, E. Essén s.n. (syn-: not localized); Sweden, Dalia, paroecia Gunnarsnäs ad Östevatten, J. Henriksson s.n. (syn-: not localized); Sweden, Ostrogothia, paroecia Landeryd ad Uvberget, P.H. Johansson s.n. (syn-: not localized).

C. avellana var. subtecta Henriksson, Botaniska Notiser 1923 (3): 283 (Henriksson 1923). - Type: Sweden, Dalia, paroecia Gunnarsnäs ad Östevatten, J. Henriksson s.n. (holo-: not localized).

C. avellana var. contracta Henriksson, Botaniska Notiser 1927 (2): 157 (Henriksson 1927). - Type: Sweden, in Blekingia ad Persborg prope Ronneby, E. Essén s.n. (syn-: not localized); Sweden, Dalia, paroecia Gunnarsnäs ad sanatorium Kroppefjäll, J. Henriksson s.n. (syn-: not localized); Sweden, Sudermannia, paroecia Husby Rekarne ad Hedskolan, G. Pettersson s.n. (syn-: not localized).

C. avellana var. nitens Henriksson, Botaniska Notiser 1927 (2): 157 (Henriksson 1927). - Type: Sweden, paroecia Gunnarsnäs ad sanatorium Kroppefjäll, J. Henriksson s.n. (holo-: not localized).

C. avellana var. prominens Henriksson, Botaniska Notiser 1927 (2): 156 (Henriksson 1927). - Type: Sweden, in Bahusia, paroecia Tanum ad Vik prope Grebbestad, V. Andersson s.n. (syn-: not localized); Sweden, paroecia Gunnarsnäs ad sanatorium Kroppefjäll, J. Henriksson s.n. (syn-: not localized).

C. avellana var. retusa Henriksson, Botaniska Notiser 1927 (2): 157 (Henriksson 1927). - Type: Sweden, Dalia, paroecia Gunnarsnäs ad sanatorium Kroppefjäll, J. Henriksson s.n. (holo-: not localized).

C. avellana var. secalina Henriksson, Botaniska Notiser 1927 (2): 156 (Henriksson 1927). - Type: Sweden, Dalia, paroecia Laxarby ad Gårdsjö, N.I. Svensson s.n. (holo-: not localized).

C. avellana var. stylifera Henriksson, Botaniska Notiser 1927 (2): 159 (Henriksson 1927). - Type: Sweden, in Vermelandia, paroecia Sillerud ad vicum Sillerud, H. Danielsson s.n. (holo-: not localized).

C. memorabilis Sennen, Plantes d'Espagne 1928, no. 7082 (1928-1929) in sched. - Type: Spain [Catalonia], Barcelone, Massif de Tibidabo, e loco, 28 May 1928, Frère Sennen s.n. (syn-: not localized; isosyn-: BM!, PH00006758, P06811312!); ibid., Barranco du Rabassalet, 28 May 1928, Frère Sennen s.n. in Exsicc. Ch. Duffour no. 6745 (syn-: not localized; isosyn-: BM!, P06809387!, P06809876!, P06809877!, P06809878!, P06809879!); ibid., 14 Aug. 1928 or 1929, Frère Sennen s.n. in Plantes d'Espagne no. 7082 (syn-: not localized; isosyn-: BM!, PH00006758, P06811312!). - Note: the description is effectively published on printed labels accompanying the type specimens (Art. 30.7, McNeill et al. 2012). The name C. memorabilis appeared on labels before [Frère Sennen in Plantes d'Espagne no. 4805 (BM!, L!, L!) and Frère Sennen s.n. (BM!)], but was lacking a description. The sterile collections from 28 May 1928 were also distributed by the Société française in 1932 (Exsicc. Ch. Duffour) and are also type material.

C. avellana var. acuta Henriksson, Botaniska Notiser 1930 (2): 149 (Henriksson 1930). - Type: Sweden, in Gotlandia, paroecia Lokrum ad Haltarve, G. Nilsson s.n. (holo-: not localized).

C. avellana var. glandifera Henriksson, Botaniska Notiser 1930 (2): 149 (Henriksson 1930). - Type: Sweden, in Gotlandia, paroecia Lokrum ad Haltarve, G. Nilsson s.n. (holo-: Not localized). 
C. avellana var. mucronata Henriksson, Botaniska Notiser 1930 (2): 149 (Henriksson 1930). - Type: Sweden, Vestrogothia, paroecia Järpås ad Simmenebol, E. Brandström s.n. (holo-: not localized).

C. avellana var. pilosa Henriksson, Botaniska Notiser 1930 (2): 149 (Henriksson 1930). - Type: Sweden, Vestrogothia, paroecia Järpås ad Simmenebol, E. Brandström s.n. (holo-: not localized).

C. avellana var. taeniensis Henriksson, Botaniska Notiser 1930 (2): 149 (Henriksson 1930). - Type: Sweden, Vestrogothia, paroecia Järpås ad Simmenebol, E. Brandström s.n. (holo-: not localized).

C. avellana var. velutina f. monstrosa Henriksson, Botaniska Notiser 1930 (2): 150 (Henriksson 1930). - Type: Sweden, Vestrogothia, paroecia Järpås ad Simmenebol, E. Brandström s.n. (holo-: not localized).

C. avellana var. brevilaciniata Henriksson, Botaniska Notiser 1931 (2): 213 (Henriksson 1931). - Type: Sweden, in Hallandia, paroecia Knäred ad Ekernahult, E. Bengtsson s.n. (holo-: not localized).

C. avellana var. coniformis Henriksson, Botaniska Notiser 1931 (2): 213 (Henriksson 1931). - Type: Sweden, Dalia, paroecia Gunnarsnäs ad Lottsbyn, M. Magnusson s.n. (holo-: not localized).

C. avellana var. divergens Henriksson, Botaniska Notiser 1931 (2): 213 (Henriksson 1931). - Type: Sweden, Dalia, paroecia Gunnarsnäs ad Lottsbyn, M. Magnusson s.n. (holo-: not localized).

C. avellana var. gracilescens Henriksson, Botaniska Notiser 1931 (2): 214 (Henriksson 1931). - Type: Sweden, Dalia, paroecia Gunnarsnäs ad Lottsbyn, M. Magnusson s.n. (holo-: not localized).

C. avellana var. indivisa Henriksson, Botaniska Notiser 1931 (2): 214 (Henriksson 1931). - Type: Sweden, in Bahusia, paroecia Brastad ad Rixö, V. Nilsson s.n. (holo-: not localized).

C. avellana var. lenticularis Henriksson, Botaniska Notiser 1931 (2): 214 (Henriksson 1931). - Type: Sweden, in Bahusia, paroecia Sanne ad Prästbol, A. Johansson s.n. (holo-: not localized).

C. avellana var. porrecta Henriksson, Botaniska Notiser 1931 (2): 214 (Henriksson 1931). - Type: Sweden, in Bahusia, paroecia Brastad ad Rixö, V. Nilsson s.n. (holo-: not localized).

C. avellana var. pyramidata Henriksson, Botaniska Notiser 1931 (2): 214 (Henriksson 1931). - Type: Sweden, in Bahusia, paroecia Brastad ad Rixö, V. Nilsson s.n. (holo-: not localized).

C. avellana var. simlicinerva Henriksson, Botaniska Notiser 1931 (2): 216 (Henriksson 1931). - Type: Sweden, in Bahusia, paroecia Brastad ad Rixö, V. Nilsson s.n. (holo-: not localized).

C. avellana var. tiliifolia Murr, Veröffentlichungen des Tiroler Landesmuseums Ferdinandeum 11: 40 (Murr 1931). - Original citation: "Silz-Mötz, am Höttinger Bild." - Type: not localized.

C. mirabilis Sennen ex Bobrov, Sovietskaia Botanica 1936 (1): 28 (Bobrov 1936b) nom. inval. pro syn. - Note: the present authors did not see any specimen with this label, but it may be the name was effectively and validly published on printed exsiccata labels just like $C$. memorabilis.

C. avellana f. monstrosa H.Lindb., Plantee Finlandice Exsiccatae no. 1123 (Lindberg 1944) nom. illegit. superfl. (later homonym) in sched., non Henriksson (1930). - Type: Finland, Usimaa/Nyland, paroecia Karis, Hållsnäs, 25 Aug. 1920, H. Lindberg s.n. (syn-: K!, WU!). - Note: this is a mutation with branched male catkins. The description is effectively published on printed labels accompanying the type specimens (Art. 30.7, McNeill et al. 2012), but illegitimate as it is a later homonym.

C. avellana f. peltata De Langhe, Bulletin de la Société Royale de Botanique de Belgique 106: 70 (Langhe 1973) nom. illegit. (later homonym), non Buser (1904). - Type: Belgium, district Mosan, 1961, J.-E. De Langhe 544/1961 (holo-: Herbarium De Langhe).

C. avellana f. microphylla Gajić \& Korac, Glasnik Prirodnaučkog Museja u Beogradu. Serija B Biološke nauke. Belgrade [Bulletin du Museum d'Histoire Naturelle Belgrade. Serie B. Sciences Biologiques. Belgrade] 33: 60 (Gajić \& Korać 1979) nom. illegit. (later homonym, Art. 53.4, McNeill et al. 2012), non C. avellana var. microphylla Lej. (Lejeune \& Courtois 1836). - Type: Serbia/Kosovo, m. Ošljak, 1450 m a.s.l., 10 Jul. 1977, M. Gajić and M. Korać s.n. (holo-: not localized).

C. hispanica Mill. ex D.Rivera, Obón, S.Ríos, Selma, F.Méndez, Verde \& F.Cano, Las Variedades Tradicionales de Frutales de la Cuenca del Río Segura. Catálogo Etnobotánico (1): Frutos Secos, Oleaginosos, Frutales de Hueso, Almendros y Frutales de Pepita: 37 (Rivera Núñez et al. 1997) nom. illegit. superfl. (later homonym), non K.Koch (Koch 1867). - Type: Spain, in Castillae Veterae, prope coenobio Sancta Clarae, in ditione Medina de Pomar (Burgos), 5 Aug. 1996, D. Rivera and 
C. Obón 47689 (holo-: MUB; iso-: MUB). - Note: Rivera Núñez et al. (1997) describe this long cultivated form as a new species, synonymizing several valid names below the species rank. Corylus avellana var. grandis Aiton. is however, already elevated to species rank by Noisette (1825), making this the oldest name for the taxon at species rank, if recognized. Futhermore, there is already a C. hispanica K.Koch, who described the same morphology. In all, C. hispanica Mill. ex D.Rivera, Obón, S.Ríos, Selma, F.Méndez, Verde \& F.Cano is a later homonym.

C. avellana var. macrotruncus Zernov, Определитель сосудистых растений севера Российского Причерноморья: 94 (Zernov 2002). - Type: Russia, Krasnodar, Novorossijsk, pylae Topolnaja-2, in valle rivuli, 18 Aug. 1999, A.S. Zernov 557 (holo-: MW; iso-: MOSP). - Note: this was described as a tree, but synonymized under C. avellana in The Plant List (2013).

C. domestica Kosenko \& Opalko, Інтродукція рослин на початку XXI століття: Досягнення i перспективи (До 120-річчяз дня народження академіка М.І.Вавилова): Матеріали Міжнародної наукової конференції (2-4 жовтня 2007 р.): 70-74 (Kosenko \& Opalko 2007) nom. nud. - Note: Kosenko \& Opalko (2007) published this name to accommodate the cultivated hazelnut, here considered as of hybrid origin from C. avellana, C. maxima, and C. avellana var. pontica. The protologue, however, lacks a type and a formal diagnosis (I. Kosenko, pers. com.), and has been used in a few Ukrainian publications mainly on hazel cultivation since then. However, the name refers to the same entity as $C$. hispanica and C. grandis, and the latter name would have priority. However, as a putative cultigen, the taxon should probably be better named following the code for cultivated plants (ICNCP, Brickell et al. 2009).

C. avellana var. alternata Henriksson nom. nud. in sched. - Associate material: Sweden, Dalia, paroecia Gunnarsnäs ad Mörtvkien, 100 m a.s.l., 30 Aug. 1926, J. Henriksson s.n. (LD1780125).

C. avellana f. coronata nom. nud. in sched. - Associate material: Sweden, Vestrogothia, paroecia Toarp, Skinnarhult, 14 Sep. 1921, O. Olson s.n. (LD1793794).

C. avellana f. sublobulata J.Erikson nom. nud. in sched. - Associate material: Sweden, Blekinge, Rödeby, 5 Sep. 1914, J. Erikson s.n. (LD1064362).

\section{2aa. Corylus avellana 'Atlas'}

C. algeriensis Oct.Thomas, Guide Pratique de l'Amateur de Fruits: 36, 213 (Thomas 1876). - Original citation: "D'Angleterre." - Type: not localized. - Note: this is a Latin name given for an English cultivar called 'Atlas'. The diagnosis is highly rudimentary, referring only to the clustered fruits.

\section{2ab. Corylus avellana 'Aurea'}

C. avellana var. aurea G.Kirchn., Arboretum Muscaviense: 670 (Petzold \& Kirchner 1864). - C. avellana f. aurea (G.Kirchn.) Dippel, Handbuch der Laubholzkunde 2: 128 (Dippel 1891) [“1892”]. - Type: not localized. - Note: Petzold was in contact to Schlechtendal in HAL (Stafleu \& Cowan 19761988), possibly original material is found there. This is a yellow-leaved garden cultivar, best called C. avellana'Aurea'.

\section{2ac. Corylus avellana 'Contorta'}

C. avellana var. contorta Bean, The Garden 54: 349 (Bean 1898). - C. avellana f. contorta (Bean) Rehder, Bibliography of Cultivated Trees and Shrubs Hardy in the Cooler Temperate Regions of the Northern Hemisphere: 111 (Rehder 1949). - Type: not localized. - Note: this is a still popular garden variety with cork-screw shaped branches that was originally discovered near Gloucester, England around the year 1850 . 


\section{2ad. Corylus avellana 'Cosford'}

C. avellana var. tenuis Loudon, Arboretum et Fruticetum Britannicum 3: 2018, fig. 1943 (Loudon 1838). - Type: iconotype (lecto-, designated here: Lindley 1829: pl. 55). - Note: Corylus avellana var. tenuis was created as a scientific name for the cultivar 'Cosford' (Lindley 1829). We argue that the cultivar name should be used for what is clearly the result of a horticultural selection process.

\section{2ae. Corylus avellana 'Fuscorubra'}

C. avellana f. fuscorubra Dippel, Handbuch der Laubholzkunde 2: 128 (Dippel 1891) [“1892”]. - Type: iconotype, Goeschke (1887: tab. 4). - Note: Dippel cites a German description of this cultivar 'Rotblättrige Waldnuss' by Goeschke (1887: 46), who found it in the arboretum of Reinhardt Behnsch in Dürrgoy (Tarnogaj) near Breslau (Wrocław, Poland). This is a red-leaved cultivar whose leaf coloration fades soon, and which has an involucre shorter than half of the nut.

\section{2af. Corylus avellana 'Impériale de Trébizonde'}

C. macrocarpa Oct.Thomas, Guide Pratique de l'Amateur de Fruits: 36, 213 (Thomas 1876). - Type: not localized. - Note: Corylus macrocarpa is a Latin name given for a cultivar called 'Impériale de Trébizonde'. The name has been published in garden catalogs before, but the present authors are unaware of an accompanying description. The cultivar is still widely grown and offered for sale.

\section{2ag. Corylus avellana 'Pendula'}

C. avellana var. pendula Nestel, Nestel's Rosengarten 2: 17 (Nestel 1869). - C. avellana f. pendula (Nestel) Dippel, Handbuch der Laubholzkunde 2: 128 (Dippel 1891) [“1892”]. - Original citation: "wurde vor einer Reihe von Herrn Niessing in einem Walde seiner Heimat entdeckt, und später als diese merkwürdige, natürliche Spielart für ihn als Gärtner erhöhtes Interesse erhielt, durch Uebertragung von Pfropfreisen und durch Ableger festgehalten." - Type: not localized. - Note: Corylus avellana var. pendula is a formal taxonomical name for a cultivar with over-hanging branches, best treated as C. avellana 'Pendula'. This garden variety was brought into cultivation by Niessing (Nestel 1869) and presented for the first time at the World Exhibition in Paris in 1867 (Goeschke 1887: 49).

\section{2ah. Corylus avellana 'Urticifolia'}

C. avellana [unranked] urticifolia Nois., Manuel Complet du Jardinier, Maraicher, Pépiniériste, Botaniste, Fleuriste et Paysagiste 2: 464 (Noisette 1825) [“urticaefolia"]. - C. urticifolia hort. ex Loudon, Arboretum et Fruticetum Britannicum 3: 2017 (Loudon 1838) nom. inval. pro syn. C. avellana var. urticifolia (Nois.) A.DC., Prodromus Systematis Naturalis Regni Vegetabilis 16(2): 131 (Candolle 1864). - C. urticifolia (Nois.) Dippel, Handbuch der Laubholzkunde 2: 128 (Dippel 1891) ["1892"]. - Original citation: "Nous l'avons vu chez M. le comte Montmorenci à Montgeron [France]". - Type: not localized. - Note: none of the later users of the epithet "urticifolia" refer to Noisette, who called it "espèce" and "variété" with the name "C. urticaefolia" (thus unranked). However, this leaf shape mutation apparently occurs spontaneously in the wild (Franz 1992). Mehlenbacher \& Smith (1995) found the trait to be encoded by a recessive gene. It is thus likely that there are multiple origins of cultivars with the variety name 'Urticifolia' (and C. avellana var. heterophylla Loudon, C. laciniata hort. ex Burchardt, and C. avellana var. quercifolia Booth et al. ex G.Kirchn.). Nevertheless, they all refer to a horticultural variety with the same mutation (therefore Art. 41.4 applies, McNeill et al. 2012), which is to be treated as C. avellana 'Urticifolia' as the earliest available name (Art. 29.1, Brickell et al. 2009). 
C. avellana var. heterophylla Loudon, Arboretum et Fruticetum Britannicum 3: 2017 (Loudon 1838). C. heterophylla Lodd., Catalogue of Plants ed. 16: [page unknown] (Loddiges 1836) nom. nud. C. avellana f. heterophylla (Loudon) Rehder, Bibliography of Cultivated Trees and Shrubs Hardy in the Cooler Temperate Regions of the Northern Hemisphere: 110 (Rehder 1949). - Type: not localized. - Note: the epithet heterophylla is problematic in Corylus. At the rank of a variety (and forma), it was formally used for a garden cultivar (C. avellana 'Urticifolia'), whereas in the rank of a species, it was only used as a mere name without description for that cultivar (nom. nud.). However, there is a species, C. heterophylla Fisch. ex. Trautv., from East Asia that must not be confused with with ornamental plant with narrow, deeply incised and double-serrate leaves. As neither Trautvetter nor Fischer referred to a cultivar, but a Siberian wild species, their name is not to be treated as a new combination (Art. 41.4, McNeill et al. 2012). The oldest epithet for the deeply incised doubleserrate C. avellana is urticifolia, C. avellana [unranked] urticifolia Nois. (Noisette 1825), hence this cultivar should be called $C$. avellana 'Urticifolia'.

C. laciniata hort. ex Burchardt, Verhandlungen des Vereins zu Beförderung des Gartenbaues in den Königlich Preußischen Staaten 15: 84 (Burchardt 1841). - C. avellana f. laciniata (Burchardt) Döll, Rheinische Flora: 273 (Döll 1843). - C. avellana var. laciniata (Burchardt) G.Kirchn., Arboretum Muscaviense: 670 (Petzold \& Kirchner 1864). - Original citation: "Ich habe meinen Stamm von den Herren Gebrüdern Baumann, die ihn von einem ihrer Reisenden aus dem südlichen Frankreich als Betula laciniata ohne Angabe des Orts erhalten hatten." - Type: most likely destroyed. - Note: there is a report that a nut collection ('Nußkabinet') existed, but it was most likely destroyed (Anonymous 1854) by Burchardt's elder son (Müller 1861). Therefore, upon publication, there was original material, but was subsequently lost. The name laciniata is a garden name that was taken up several times independently (see $C$. avellana $\mathrm{f}$. laciniata and $C$. avellana var. laciniata). The oldest publication is by Theodor Heinrich Otto Burchardt (13 Dec. 1771-6 Feb. 1853, cf. Müller 1861), justice councellor ('Justizrat') from Landsberg a. d. Warthe (now Gorzów Wielkopolski, Poland), who described it as a new species. He mentioned that he had the stock from the Pépinières Baumann from Bollwiller (Alsace, France), a then famous seed seller, who had received the material from Southern France under the name Betula laciniata. Burchardt mentioned that the plant is also to be found in the catalog of the Frères Audibert (Audibert 1831-1832), where it is listed without a description. The name, however, had already been used in seed catalogs before (Dailledouze \& Dailledouze 1828). Although neither Döll nor Kirchner explicitly referred to Burchardt, they referred to the same mutation, and their names are thus to be treated as new combinations (Art. 41.4, McNeill et al. 2012).

C. serenyiana Pluskal, Oesterreichisches Botanisches Wochenblatt 2: 394 (Pluskal 1852). - C. avellana var. serenyiana (Pluskal) Pluskal, Verhandlungen des Zoologisch-Botanischen Vereins in Wien 3 (2): 22 (Pluskal 1853). - Original citation: "an dem Ufer eines Baches bei Lomnitz [Lomnice u Tišnova, Czech Republic]". - Type: not localized. - Note: Pluskal mentioned that his plan to describe his name was highly disputed since it closely corresponded to C. avellana var. laciniata, but he insisted on describing it as a new species as he found it in the wild and reported it as new to Moravia.

C. avellana var. quercifolia Booth et al. ex G.Kirchn., Arboretum Muscaviense: 670 (Petzold \& Kirchner 1864). - C. quercifolia hort. ex A.DC., Prodromus Systematis Naturalis Regni Vegetabilis 16 (2): 131 (Candolle 1864) nom. inval. pro syn. - Note: Rehder (1949) listed this garden variety as a synonym to his $C$. avellana $\mathrm{f}$. heterophylla.

C. avellana var. incisa André, L'art des jardins: 574 (André 1879). - Type: not localized.

C. avellana var. pinnatifida Plan. nom. nud. in sched. - Associate material: Sweden, Östergötland, Regna, s. coll., s.n. (L1559661!) [N.J. Andersson ex S, pers. com.]; Sweden, Östergötland, Regna, [misit Jul. 1867], s. coll, s.n. (K!, MANCH!) [F. Ahlberg, pers. com.]; Sweden, prope Regna Ostergothia, 12 Jul. 1867, E. Rathsman s.n. (BM! K!, K!, K!, LD1790934, MANCH!, OHN135122); Sweden, OG, Regna, 1 Jun. 1865, E. Rathsman s.n. (BM!, LD1798977); Sweden, Ostergothia, Regna, Aug. 1873, A. Magnusson s.n. (P06809852!). - Note: this name is found on Swedish specimens of C. avellana 
'Urticifolia'. The name is apparently by J.E. Planander, but the present authors are not aware of a valid publication.

\section{2ai. Corylus avellana 'Variegata'}

C. avellana var. variegata A.DC., Prodromus Systematis Naturalis Regni Vegetabilis 16 (2): 131 (Candolle 1864). - C. avellana f. variegata (A.DC.) Dippel, Handbuch der Laubholzkunde 2: 128 (Dippel 1891) [“1892"]. - Type: not localized. - Note: Candolle summarized with this name C. avellana cultivars with white, yellow or red-variegated leaves.

\section{2b. Corylus avellana var. pontica (K.Koch) H.J.P.Winkl.}

Das Pflanzenreich IV 61 (Heft 19): 47 (Winkler 1904). - C. pontica K.Koch, Linnaea 22: 329 (Koch 1849). - Original citation: "Auf der Nordseite des pontischen Gebirges auf Augitporphyr bis 2500' Höhe." - Type: not localized. - Note: Corylus avellana var. pontica is recognized by Flora of the USSR (Bobrov 1936a) and World Checklist and Bibliography of Fagales (Govaerts \& Frodin 1998). It apparently differs from $C$. avellana var. avellana by double-serrate bracts that surpass the nut and are apically prominently veined. This morphology is also widely found elsewhere and particularly common in cultivars. Therefore Kosenko (2002) hypothesized that the domesticated hazel might be a hybrid involving or directly selected from $C$. avellana var. pontica. The eastern origin of hazel cultivation seems to find support in the ancient Roman name "nux pontica", supposedly first introduced from Pontus (Pliny the Elder 77-79). Koch neither mentions the Romans, nor any cultivars. Koch mentions that the nuts resemble those of C. colurna and refers to a wild collection. However, given that hazels freely intercross within the subsections (Erdoğan 1999; Erdoğan \& Mehlenbacher 2000) and that hazels have been bred for centuries, the persistence of a "pure" genotype "var. pontica" in the wild (if it ever existed) is more than doubtful.

C. pontica var. glandulifera K.Koch, Linnaea 22: 330 (Koch 1849). - C. colurna var. glandulifera (K.Koch) A.DC., Prodromus Systematis Naturalis Regni Vegetabilis 16 (2): 132 (Candolle 1864). Original citation: no collections cited. - Type: not localized.

C. imeretica Kem.-Nath., Trudy Tbilisskogo Botaniceskogo Instituta 1: 111 (Kemularia-Nathadze 1933). - Type: Georgia, prov. Kutais, distr. Schorapani, fauces fl. Kvirila, prope urb. Tschiathura ad rupes calcareas, 26. Jul. 1930, L.M. Kemularia-Nathadze s.n. (syn-: LE [photo at E, K], TBI1024989!); Georgia, prov. Kutais, distr. Letschchum, fauc. fl. Rioni, prope pag. Atscharis-chidi ad rupes calcareas, 29 Jul. 1929, L.M. Kemularia-Nathadze s.n. (syn-: not localized). - Note: Corylus imeretica was synonymized under C. avellana var. pontica by Rehder (1949).

\section{Corylus chinensis Franch.}

Journal de Botanique (Morot) 13: 197 (Franchet 1899). - C. colurna var. chinensis (Franch.) Burkill, The Journal of the Linnean Society. Botany 26: 503 (Burkill 1899). - Original citation: "China occidentalis, provincia Yunnan, in silvis montanis faucium ad San thang kiou, in via e Tali ad Ho kin, alt. 2200 m (Delavey, nn. 197 et 212)". - Type: China, Yunnan, San Tchang Kiou, Ho Kin, 2200 m a.s.1., 27 Aug. 1884, J.M. Delavay 197 [P212] (lecto-, designated here: P06811315!; isolecto-: B 10 0464027!, P06811316!, P06811317!, P06811318!, P06811319!, P06811320!, P06811321!, P06811335!, P06881735!). - Note: Corylus chinensis is recognized in the Flora of China (Li \& Skvortsov 1999), Flora Sichuanica (Editorial Board of the Flora Sichuanica 2012), and World Checklist and Bibliography of Fagales (Govaerts \& Frodin 1998). The specimen chosen as a lectotype here bears two numbers: "no. 197" (with the number circled) and "no. 212." There are different numbering systems in Delavay's collections (Holstein \& Weigend 2016a), and the 197 is Delavay's original number. The number " 212 " is apparently the specimen number placed on the sheet at the Paris herbarium, which is also found on specimen P06811321. 
C. papyracea Hickel, Bulletin de la Société Dendrologique de France 68: 94 (Hickel 1928). - Type: Cult. in Frutic. Vilmorinianum olim. cult., R. Hickel s.n. (lecto-, designated here: P06811311!). Additional original material: Cult. in Frutic. Vilmorinian., Sep. 1910, R. Hickel s.n. (P06811310!). Note: Corylus papyracea is listed as a synonym of C. chinensis in the Flora of China (Li \& Skvortsov 1999), in the Flora Sichuanica (Editorial Board of the Flora Sichuanica 2012), and in the World Checklist and Bibliography of Fagales (Govaerts \& Frodin 1998). The material for the description of this "species" was only observed in cultivation and according to the author, it already had disappeared 10 years before publication. Hickel mentions that Vilmorin believed that the seeds were from China and had been originally collected by P.G. Farges in 1904. The lectotype was chosen because the upper right leaf is the one shown in the illustration accompanying the protologue. The other specimen bears the unpublished name "Corylus papyrifera", but does not differ from the lectotype. Possibly, that name was a working name.

C. chinensis var. macrocarpa Hu, Bulletin of the Fan Memorial Institute of Biology, Botany 8: 32 (Hu 1937). - Type: China, Yunnan, Wai-Si Hsien, Yeh Chih wa-rung, 3400 m a.s.1., Aug. 1935, C.W. Wang 68308 (holo-: PE00802441!; iso-: A00033779!, PE00802422!, PE00802446!, PE00802445!, PE00802439!, PE00802430!). - Note: Corylus chinensis var. macrocarpa is listed as a synonym of C. chinensis in the Flora of China (Li \& Skvortsov 1999), Flora Sichuanica (Editorial Board of the Flora Sichuanica 2012), and World Checklist and Bibliography of Fagales (Govaerts \& Frodin 1998).

\section{Corylus colchica Albov}

Prodromus Florae Colchicae: 219 (Albov 1895). - Original citation: "Hab. in Mingrelia: ad rupes calcareas montinum Dzhwari et Migaria (supra pagum Kurdzu), 1900-2000 m, (N. A. 1893, nos 500, 501)." - Type: Georgia, [Samegrelo-Zemo Svaneti], Mingrélie, Mt. Djwari [Jvari], frontière de la forêt, 25 Aug. 1893, N.M. Alboff 501 (lecto-, designated here: G00418165!). - Additional type material: Georgia, [Samegrelo-Zemo Svaneti], Mingrélie, Mt. Migaria, 2000 m a.s.l., Aug. 1893, N.M. Alboff 500 (syn-: G00418164!). - Note: Corylus colchica is recognized in the Flora of the USSR (Bobrov 1936a) and in the World Checklist and Bibliography of Fagales (Govaerts \& Frodin 1998). According to Bobrov (1936a), the type is in G, whereas a duplicate is found in LE. However, it is not mentioned, which of the two syntype specimens is to be regarded as the lectotype (Bobrov 1936a: 267), therefore, we designate one. The existence of a LE duplicate could not be confirmed (LE, pers. com.).

\section{Corylus colurna $\mathrm{L}$.}

Species Plantarum: 999 (Linnaeus 1753). - C. tubulosa var. colurna (L.) Risso, Histoire Naturelle des Principales Productions de l'Europe Méridionale et particulièrement de Celles des Environs de Nice et des Alpes Maritimes 2: 333 (Risso 1826) nom. illegit. superfl. - Orignal citation: "Habitat Byzantii." - Type: Herb. Linn. no. 1132.4 (lecto-, designated by Browicz 1972: 5: LINN!). - Note: Corylus colurna is recognized in the Flora of the USSR (Bobrov 1936a), in the Flora Europaea (Tutin \& Walters 1993), and in the World Checklist and Bibliography of Fagales (Govaerts \& Frodin 1998).

C. arborescens Münchh., Hannover'sche Gelehrte Anzeigen 3 (61): 929 (Münchhausen 1754). Original citation: "Es ist bekannt, daß es an einigen Orten, als in Frankfurt" [am Main, Germany, in the garden of the Merchant du Fay (Burchardt 1833)] (...) "Ich habe dergleichen selber bey mir". Type: not localized. - Note: the Frankfurt Hazel tree was very well known back then, and it was speculated that it was the same one that was introduced by Clusius in the end of the $16^{\text {th }}$ century that he obtained from the Austrian baron von Ungnad from Constantinople (Goeschke 1887). The authorship of the name $C$. arborescens is not obvious, as the article is only cited as "S. im Jul 1753. 
M.". However, the name C. arborescens is usually attributed to Münchhausen, the author of the horti- and agricultural book "Der Hausvater" who owned an estate called Schwöbber near Hameln in Lower Saxony, Germany. Given that the protologue is published in a journal from Lower Saxony, it is reasonable to assume Münchhausen's authorship of $C$. arborescens.

C. byzantina P.Herm. ex Mill., The Gardeners Dictionary ed. 7 [unnumbered] (Miller 1759) nom. inval. pro syn. - Original citation: "Byzantine." - Type: not localized. - Note: Miller used this name in synonymy, as he did not adopt binomials until the $8^{\text {th }}$ edition of his The Gardeners Dictionary (Miller 1768). There, Miller synonymizes C. byzantina under C. colurna. Originally, Miller cited Linnaeus' Hortus Cliffordianus (Linnaeus 1737: 448) and Hermann (1687: 121). The latter refers to Caspard Bauhin's Avellana peregrina humilis (Bauhin 1623: 418) and Jean Bauhin et al.'s Avellana byzantina (Bauhin et al. 1650: 270), both of which were also cited by Linnaeus (1737). A cluster of nuts with deeply laciniate bracts is depicted in Bauhin et al. (1650), clearly what is nowadays regarded as C. colurna, and consistent to his later synonymization.

C. nana Tourrette \& Rozier, Démonstrations Élémentaires de Botanique 3: 448 (La Tourrette \& Rozier 1787). - Type: not localized. - Note: the authors just gave description and the species' origin, but do not refer to any earlier publication. However, given the origin and description, they mean the lowgrowing form of the Byzantine Hazel (C. colurna). Original material might be found in Claret de La Tourrette's or in Rozier's herbarium, both held at LYJB.

C. macedonica V.Cordus \& Gesner ex Strelin, Realwörterbuch für Kameralisten und Oekonomen 4: 528 (Strelin 1788). - Type: Germany, [cult.] in Schwöbber. [originally from Macedonia, cult. by Münchhausen in Schwöbber estate, Lower Saxony, Germany]. - Type: not localized. - Note: It was described as a tree in contrast to C. colurna that was, incorrectly, considered to be a shrub. Basically, this is another name for Münchhausen's $C$. arborescens.

C. avellana var. glomerata Aiton, Hortus Kewensis 3: 363 (Aiton 1789). - C. glomerata (Aiton) Nois., Manuel Complet du Jardinier, Maraicher, Pépiniériste, Botaniste, Fleuriste et Paysagiste 2: 464 (Noisette 1825). - Original citation: "Corylus nucibus in racemum congestis" (Bauhin 1623). Note: apparently a hazel from Macedonia [Balkan peninsula] growing as a tree with clustered fruits. Bauhin's citations lead to a short description by Cordus (1561: 25r) without a figure. According to the descriptions, this is C. colurna.

C. colurna var. avellanoides Spach, Annales des Sciences naturelles, seconde série - Botanique 16: 104 (Spach 1841). - Type: Cult. in H[ortus] P[arisiensis], (E), 1834, s. coll., s.n. in Herb. Spach (lecto-, designated here: P06809956!).

C. colurna var. brachycarpa Spach, Annales des Sciences naturelles, seconde série-Botanique 16: 103 (Spach 1841). - Type: iconotype, Watson (1823-1825: tab. 99).

C. colurna var. leptochlamys Spach, Annales des Sciences naturelles, seconde série - Botanique 16: 104 (Spach 1841). - Type: Cult. in H[ortus] P[arisiensis], 1841, s. coll., s.n. in Herb. Spach (lecto-, designated here: P06809951!).

C. colurna var. macrochlamys Spach, Annales des Sciences naturelles, seconde série - Botanique 16: 104 (Spach 1841). - Type: Cult. in H[ortus] P[arisiensis], 1841, s. coll., s.n. in Herb. Spach (lecto-, designated here: P06809954!).

C. colurna var. trichochlamys Spach, Annales des Sciences naturelles, seconde série-Botanique 16: 104 (Spach 1841). - Type: Cult. in H[ortus] P[arisiensis], Ménagerie, 1835, s. coll., s.n. in Herb. Spach (lecto-, designated here: P06809953!). - Additional original material: Cult. in H[ortus] P[arisiensis], 1827, s. coll., s.n. in Herb. Spach (P06809955!); cult. in H[ortus] P[arisiensis], Ménagerie, 1835, s. coll., s.n. in Herb. Spach (P06809955!); cult. in Hort[us] Par[isiensis], 1841, s. coll., s.n. in Herb. Spach (P06809955!); s.d., s. coll., s.n. (P06810646!, P06810647!).

C. cervorum Petrov, Byulleten' Moskovskogo Obshchestva Ispytatelei Prirody, Otdel Biologicheskii n.s., 45: 121 (Petrov 1936). - Type: Azerbaijan, Karabagh, Querceto-coryleta in decliviis vallis fl. Khoross [Kores] superiori, alt ci[rc]a 1200-1400 m supra nivem maris, I. Petrov s.n. (holo-: not localized). 
C. iberica Wittm. ex Kem.-Nath., Trudy Tbilisskogo Botaniceskogo Instituta 6: 11 (Kemularia-Nathadze 1938). - Type: Georgia, Iberia, in sylvis montanis, Sep. 1843, Wittman 351 (syn-: not localized; isosyn-: BM!, K000859912!); Georgia, prov. Kuthaisi, Ratscha, Tschelischskaya datscha, 25 Aug. 1910, Fijenko s.n. (syn-: not localized); Georgia, Ratscha, Teschelishis Udabno prope pag. Nikortzminda in calcar., 16 Sep. 1929, L.M. Kemularia-Nathadze s.n. (syn-: not localized); Georgia, [no locality given], 20 Oct. 1937, L.M. Kemularia-Nathadze s.n. (syn-: not localized); Georgia, Лec около сеп. Горолеша [in silva Gorolesha], известн [limestone], 20 Oct. 1937, L.M. KemulariaNathadze s.n. (syn-: not localized); Georgia, prov. Tiflis, distr. Duschethi, fauces Gudamakhari, loc. Thchemliani, 1903, A. Fomin s.n. (syn-: not localized); Georgia, prov. et distr. Tiflis, Saguramo, 25 Jul. 1917, L.M. Kemularia-Nathadze s.n. (syn-: not localized); Georgia, Udzo, prope Tblisi, 16 Aug. 1937, L.M. Kemularia-Nathadze s.n. (syn-: not localized); Georgia, distr. Manglis, prope pag. Prijut, 9 Jul. 1903, A. Fomin s.n. (syn-: TBI1006417!); Georgia, [without locality], 28 Mar. 1936, L.M. Kemularia-Nathadze s.n. (syn-: not localized); Georgia, in faucibus fl. Algeti, 22 Aug. 1924, L.M. Kemularia-Nathadze s.n. (syn-: not localized); Georgia, distr. Aghbulach in silva Gudarethi (in calcar.), 28 Aug. 1937, L.M. Kemularia-Nathadze s.n. (syn-: not localized); Georgia, distr. Thionethi, Chisso, 29 Aug. 1935, I.I. Tumadjanov s.n. (syn-: not localized); Georgia, distr. Signach, prope pag. Lagodechi, 29 Sep. 1905, E. Koenig s.n. (syn-: not localized). - Note: the L.M. KemulariaNathadze's specimen from 28 Mar. 1936 was not listed in the specimen list in Russian. Corylus iberica is regarded as a synonym of $C$. colchica (The Plant List 2013), but as Kosenko pointed out, it is more likely synonymous to C. colurna (Kosenko 2002) in agreement to Bobrov (1936b). Corylus iberica and C. colurna are both supposed to growth as trees and share the clustered nuts with laciniate bract margins.

C. iberica var. glandulosa Kem.-Nath., Trudy Tbilisskogo Botaniceskogo Instituta 6: 15 (KemulariaNathadze 1938). - Original citation: "Вместе с типичной формой, часто.” [Together with typical form, common.]. No specimens cited. - Type: not localized.

C. abchasica Kem.-Nath., Zametki po Sistematike i Geografii Rastenii. Tiflis 35: 3 (Kemularia-Nathadze 1978). - C. colchica var. abchasica Kem.-Nath., Flora Gruzii 3: 40 (Ketskhoveli et al. 1975) nom. inval. (without Latin description). - Type: Georgia, Abkhazia, Abchazia occid., ad pedem merid. montis Arabica, in fruticetis subalpinis, ca. $6000 \mathrm{ft}$., G. Woronow 139 (holo-: not localized; iso-: TBI1005852!). - Additional type material: Georgia, Abkhazia, mons Karschlara inter montem Mamdzischcha et Kutysch ad rupes calcareas; jugum Bzibi, m. Japsu, 28 Mar. 1948, N. Purtzchvanidze s.n. (para-: TBI1005851!, TBI1005853!); Georgia, Abkhazia, Tscherkesskaja polyana, 29 Jul. 1934, A.G. Doluchanov s.n. (para-: TBI1005849!); Georgia, distr. Gudauty, in jugo Chitsma, in monte "Lyssaja gora", 27 Jul. 1929, M. Gubbis s.n. (para-: TBI1005856!); Georgia, Abkhazia, Suchum, in monte Apianča [Apiantcha], 29 May 1927, S. Petjaev s.n. (para-: TBI1005858!). - Note: There is a typographical error in the Latin translation of the specimen list of C. abchasica: the paratype collection of N. Purtzchvanidze is listed in the Latin section as being from March, but the month is written in Roman numerals on the sheets and in the Russian text, and so the forgotten "V" changes the original August (VIII) to March (III).

C. egrissiensis Kem.-Nath., Zametki po Sistematike i Geografii Rastenii. Tiflis 35: 6 (KemulariaNathadze 1978). - Type: Georgia, Megrelia, in silva montis Quibia prope pag. Salchino, 21 Jul. 1953, L.M. Kemularia-Nathadze s.n. (lecto-, designated here: TBI1006350!; isolecto-: TBI1006351!). Additional type material: Georgia, Abkhasia, Prope Novi-Athoni [Novy Afon], angustiae Psychra, 300 m a.s.l., 24 Jul. 1934, A. Doluchanov s.n. (para-: TBI1006337!); Georgia, Abkhasia, Gagri ad ripas flum. Djovekwara, 16 Oct. 1939, W. Sherozia s.n. (para-: not localized); Georgia, Abkhasia, vicinis Gagri, 29 Jul. 1912, J. Gusev s.n. (para-: TBI1006334!); Georgia, Abkhasia, pag. Otradnoe inter Bzipi et Gegi [in hortis Otradnoe], 3 Jul. 1929, S. Saakov s.n. (para-: TBI1006339!); Georgia, Abkhasia, distr. Suchum, in m. Byrtsch, 4 Jul. 1927, s. coll.?, s.n. (para-: not localized); Georgia, Abkhasia, Gudauthi et Kaldachvara, 24 Jun. 1927, s. coll.?, s.n. (para-: not localized); Georgia, Abkhasia, prope som. Kamany, 29 Jun. 1930, S. Petjaev s.n. (para-: TBI1006336!); Georgia, 
Abkhasia, in fauces fl.September Gumista, 26 Jun. 1927, Nikolaev s.n. (para-: not localized); Georgia, Svanetia, prope pag. Chaischi [Khashi] in angust. fl. Tcheischi [Tkheishtshi] et Chaischura [Khaishuru], 23 Jul. 1937, L.M. Kemularia-Nathadze and A. Kharadze s.n. (para-: TBI1006345!); Georgia, Megrelia, vicinis pag. Salchino in angustis fl. Tzatschcuris, 20 Jul. 1953, L.M. KemulariaNathadze s.n. (para-: not localized); Georgia, Adjaria, distr. Batumi, angustiae prope pag. Macrial, 1908, I. Woronov and E. Bobrov s.n. (para-: not localized). - Note: the lectotype of C. egrissiensis was designated because the protologue does not indicate a herbarium, and there are two specimens in TBI.

C. kachetica Kem.-Nath., Zametki po Sistematike i Geografii Rastenii. Tiflis 35: 5 (Kemularia-Nathadze 1978). - C. kachetica Kem.-Nath., Flora Gruzii 3: 40 (Ketskhoveli et al. 1975) nom. inval. (without Latin description). - Type: Georgia, Pshavi: Angustiae Gometsari, 28 Jul. 1935, N. Ketzkoveli s.n. (lecto-, designated here: TBI1006504!; isolecto-: TBI1006505!). - Additional type material: Georgia, Kachetia, Лагодехи ущелье [Lagodekhi Gorge] р. Апцал [Aptsal river], 22 Aug. 1938, A.G. Doluchanov s.n. (para-: not localized); Georgia, ущ. p. Качал [gorge of Kakhal river], 10 May 1939, L.M. Kemularia-Nathadze s.n. (spara-: not localized); Georgia, Kachetia, Напареули, Дидихеви [Napareuli, Didikhebu], 12 Jul. [Aug.?] 1936, P.P. Zagareli s.n. (para-: TBI1006501!?); Georgia, Телавский район [Telavi district], около деревии Цагаури [near Zagauri forest], долина Турдо [Turdo valley], 1 Sep. 1958, S. Kutatenadze et al. s.n. (para-: TBI1006506!). - Note: The Zagareli specimen (TBI1006501) matches the locality and date except for the month (August instead of July as in the protologue). Possibly, there was a typographical error in the publication.

\section{Corylus $\times$ colurnoides C.K.Schneid.}

Illustriertes Handbuch der Laubholzkunde 1: 145 (Schneider 1904) [“1906"]. - Original citation: "In Hann. Münden, September 1903, C.K. Schneider". - Type: not localized. - Note: Hybrid between C. colurna $\times$ C. avellana. Recognized by Flora of The USSR (Bobrov 1936a) and World Checklist and Bibliography of Fagales (Govaerts \& Frodin 1998).

C. $\times$ fominii Kem.-Nath., Trudy Tbilisskogo Botaniceskogo Instituta 6: 15 (Kemularia-Nathadze 1938).Type: Georgia, Hortus Botanicus Thbilisiensis (Sect. Silva Georgiae Orient), 16 Aug. 1935, L.M. Kemularia-Nathadze s.n. (syn-: not localized); ibid., 11 Mar. 1936, L.M. Kemularia-Nathadze s.n. (syn-: TBI1024984!, TBI1024985!); ibid., 16 Aug. 1937, L.M. Kemularia-Nathadze s.n. (syn-: not localized).

C. $\times$ gudarethica Kem.-Nath., Trudy Tbilisskogo Botaniceskogo Instituta 6: 17 (Kemularia-Nathadze 1938). - Type: Georgia, prov. Tblisi, distr. Aghbulach prope pag. Gudarethi in silva (solo calc.), 28 Aug. 1937, L.M. Kemularia-Nathadze and R. Zagareli s.n. (holo-: TBI1006382!). - Note: although most type material of other names of Kemularia-Nathadze has not been found in TBI (most likely housed in LE), the holotype of $C . \times$ gudarethica is localized there. The figure on page 19 is a drawing of the specimen TBI1006382, so this is what the author referred to as $C . \times$ gudarethica is supposedly the hybrid of C. iberica (C. colurna) and C. avellana, while in C. $\times$ fominii, the parents (parental sexes) are reversed.

\section{Corylus cornuta Marshall}

Arbustrum Americanum: 37 (Marshall 1785). - Type: Cult. in Hort. Marshall., 14 Sep. 1835, s. coll., s.n. (neo-, designated here: DWC!). - Note: Humphry Marshall's original collection is located in DWC with some specimens also in BM (Stafleu \& Cowan 1976-1988). However, there is apparently no extant specimen that can be regarded as original material (S.E. Bartholomew-Began, pers. com.). The specimen chosen here as neotype is from Marshall's Garden, but collected about 50 years later. As it contains a fruit in its striking horn-like involucre, it allows unambiguous identification. 
7a. Corylus cornuta Marshall subsp. cornuta

Note: it has been recognized as having two subspecies by Flora of North America (Furlow 1997) and World Checklist and Bibliography of Fagales (Govaerts \& Frodin 1998).

C. rostrata Aiton, Hortus Kewensis 3: 364 (Aiton 1789). - Original citation: "Cult. [since] 1745 by Archibald Duke of Argyle" [sic!, Archibald Campbell, third Duke of Argyll, who laid the groundstock for Kew Botanical Gardens] and "Nat. of North America." Material from the cited Gronovius (1762): "Crescit in Dragon swamps" [a river in Virginia, USA]. - Type: Cult., Hort. Bni [Botanici] Collinson, Mill Hill, s. coll., s.n. (neo-, designated here: BM001191197!). - Note: the first author did not find any original material in the relevant herbaria. In order to explore which material might be taken into account, we briefly discuss the origin of the name here. As there is no explicit indication of an author, the name is to be attributed to Aiton (Art 46.8. ICN, McNeill et al. 2012). However, the original author of C. rostrata is apparently Daniel Carlsson Solander. Although the third volume was mainly edited by Dryander (Stafleu \& Cowan 1976-1988), Dryander largely used Solander's manuscripts (Britten 1912), and in the Linnean herbarium, there is a specimen of what is now understood as C. cornuta (LINN 1132.2) where J.E. Smith writes " $C$. rostrata Mss. 83. 931" and "C. rostrata Soland[er] Ait. H. Kew v.3 364." As a contemporary of the publication, Smith likely knew who the author of the name was, while 81 and 931 might be interpreted as manuscript fragments. Therefore, possible original material needs to be linked to Solander's collections. Two sources are cited in the protologue, material from Duke Argyll's garden and Gronovius' Flora Virginica ed. 2 (Gronovius 1762). Material from Gronovius is usually found in the Clayton Herbarium (Stafleu \& Cowan 1976-1988), but there appears to be no original material of this taxon. Also, the number cited for Clayton's herbarium in Gronovius' Flora Virginica ed. 2 is erroneous, because Clayton 747 is a Juglans sp., which is already cited on the previous page. There is a specimen in BM (BM001191197) by Peter Collinson (1694-1768) from Mill Hill, where Collinson lived from 1749 on (Living \& Braithwaite 2013). Collinson obtained material from Gronovius for cultivation (Reveal \& Pringle 1993), and Collinson was also in contact with Solander. Thus, the specimen might be derived from Gronovius' collection. In addition, as a student of Linnaeus, Solander had access to his herbarium, so the LINN specimen (LINN 1132.2) might also be taken into consideration. However, neither Collinson's specimen nor the one from the Linnean herbarium can unambiguously linked to Solander, so they are not original material, making a neotypification necessary. Due to be possible link and the completeness of the specimen, we choose the specimen from Collinson's garden as neotype.

C. cornuta f. inermis Fernald, Rhodora 38: 76 (Fernald 1936). - Original citation: "Quebec: abundant in border of woods, East Broughton". - Type: Canada, Quebec, East Broughton, 28 Aug. 1915, M.L. Fernald and H.B. Jackson 12073 (holo-: GH).

C. cornuta var. megaphylla Vict. \& Rousseau, Contributions de l'Institut Botanique de l'Universite de Montréal 36: 13 (Marie-Victorin \& Rousseau 1940). - Type: Canada, Quebec, Matapédia, sur les îles de la Restigouche, à l'embouchure de la Matapédia (frontière du Nouveau-Brunswick), 15 Aug. 1928, J.L.C. Marie-Victorin and Rolland-Germain 28690 (lecto-, designated here: MT00132174!; isolecto-: MT00132175!). - Additional type material: Canada, Quebec, thickets and borders of woods, near mouth of Marsouin River (Gaspé Co.), 26 Jul. 1922, M.L. Fernald and A.S. Pease 25014 (syn-: MT00206842!). - Note: Marie-Victorin \& Rousseau cited the two collections and mentioned that the type is in the herbarium of the Universite de Montreal (MT). However, there are two specimens of Marie-Victorin and Rolland-Germain 28690 in MT, of which one is annotated as a type, and one specimen of Fernald and Pease 25014 (Geoffrey Hall, MT, pers. com.). The annotated specimen is here formally designated as lectotype. 
7b. Corylus cornuta subsp. californica (A.DC.) A.E.Murray

Kalmia 12: 19 (Murray 1982). - C. rostrata var. californica A.DC., Prodromus Systematis Naturalis Regni Vegetabilis 16 (2): 133 (Candolle 1864). - C. californica (A.DC.) Rose, Garden \& Forest 8: 263 (Rose 1895). - C. cornuta var. californica (A.DC.) Sharp, Relationships between the Floras of California and Southeastern United States: 58 (Sharp \& James 1951). - Type: USA, California, 1848, K.T. Hartweg 1960 (lecto-, designated here: G-DC! (G00478869); isolecto-: BR!, G00418163!, GH00033775!, K000859889!, K!). - Note: Corylus cornuta subsp. californica is recognized in Flora of North America and World Checklist and Bibliography of Fagales (Govaerts \& Frodin 1998). The name C. californica was published twice before Rose's combination. Petzold \& Kirchner (1864: 671) mention a plant in the park of Schloss Sanssouci Garden in Potsdam, Germany, but neither provide a description, nor explicitly recognize it as something different from C. avellana, therefore their name is invalid. Koch (1873: 15) also mentions a C. californica, but also mentions only its status as a cultivated plant without providing a description. Neither of the publications refers to Candolle, therefore, Rose's combination is the first valid publication of this name.

C. rostrata var. tracyi Jeps., A Manual of the Flowering Plants of California: 271 (Jepson 1923). - Original citation: "Humboldt Co. to Siskiyou Co. and S. in the Sierra Nevada." - Type: USA, California, Humboldt Co., Grouse Mountain, 5000 ft., 2 Sep. 1917, J.P. Tracy 4842 (holo-: UC198569!).

C. cornuta var. glandulosa B.Boivin, Phytologia 15: 420 (Boivin 1967). - C. cornuta f. glandulosa (B.Boivin) T.C.Brayshaw, Catkin bearing Plants of British Columbia 18: 157 (Brayshaw 1976). Type: Canada, British Columbia, head of Finlayson Arm below Mt. Finlayson, north of Victoria, 16 Jul. 1961, J.A. Calder and K.T. MacKay 31517 (holo-: DAO).

\section{Corylus fargesii (Franch.) C.K.Schneid.}

Illustriertes Handbuch der Laubholzkunde 2: 896 (Schneider 1912). - C. rostrata var. fargesii Franch., Journal de Botanique (Morot) 13: 199 (Franchet 1899). - C. mandshurica var. fargesii (Franch.) Burkill, The Journal of the Linnean Society. Botany 26: 505 (Burkill 1899). - C. chinensis var. fargesii (Franch.) Hu, Iconographia Cormophytorum Sinicorum 1: 397 (Hu 1972). - Original citation: "China occidentalis, provincia Sutchuen, in silvis as Héoupin prope Tchen keou tin, alt. 1400 m." - Type: China, Sichuan, Tchen-Keon-Tin, 1400 m a.s.l., P.G. Farges 1307 (lecto-, designated here: P06811278!; isolecto-: A00033782!, P06810989!, P06810990!, P06810991!, P06811279!, P06811280!, P06811281!, P06811282!). - Note: Corylus fargesii was recognized in the Flora of China (Li \& Skvortsov 1999), Flora Sichuanica (Editorial Board of the Flora Sichuanica 2012), and World Checklist and Bibliography of Fagales (Govaerts \& Frodin 1998).

\section{Corylus ferox Wall.}

Plantae Asiaticae Rariores 1: 77 (Wallich 1830). - Type: Nepal, ad cacumen Sheopore montis, 1821, N. Wallich, Wallich Catalogue no. 2797 (lecto-, designated here: K001117111!; isolecto-: BM001191572!, BM001191573!, E00020277!, K000859893!).

\section{9a. Corylus ferox Wall. var. ferox}

Note: Corylus ferox var. ferox and C. ferox var. tibetica were recognized in the Flora of China (Li \& Skvortsov 1999) and World Checklist and Bibliography of Fagales (Govaerts \& Frodin 1998) as two distinct varieties of C. ferox. 
9b. Corylus ferox var. tibetica (Batalin) Franch.

Journal de Botanique (Morot) 13: 201 (Franchet 1899). - C. tibetica Batalin, Trudy Imperatorskago S.-Peterburgskago botanicheskago sada. Acta Horti Petropolitani 13: 102 (Batalin 1893). Type: China, Hubei, Mar. 1889, A. Henry 6778 (syn-: not localized; isosyn-: BM!, K000859906!, K000859907!); China, Gansu, 10 Jul. 1885, G.N. Potanin s.n. (syn-: LE; isosyn-: K000859909!, K000859910!, P06810950!, PE00021984!). - Note: Corylus ferox var. tibetica was recognized as a distinct species in the Flora Sichuanica (Editorial Board of the Flora Sichuanica 2012).

10. Corylus heterophylla Fisch. ex. Trautv.

Plantarum Imagines et Descriptiones Floram Russicam Illustrantes 1: 10, fig. 4 (Trautvetter 1844). C. tetraphylla Fisch. ex Ledeb., Denkschriften der Königlich-Baierischen Botanischen Gesellschaft in Regensburg 3 (2): 58 (Ledebour 1841) nom. nud. (sphalm. for C. heterophylla Fisch.). -C. avellana var. davurica Ledeb., Flora Rossica 3 (2): 588 (Ledebour 1850) [“1850-1851"]. - Original citation: "Delineavi ad specimina Argunensia sicca." - Type: Russia, ad fl. Argun, s. coll., s.n. (lecto-, designated here: LE01012787!). - Additional original material: Russia, ad fl. Argun, [comm.? leg.?] 1836, F.E.L. Fischer 5 (BR!, P06810938!); Russia, ad alterum litteri Arguni in Dahuria chinensi, 1820, C.F. von Ledebour s.n. (P06810936!); Russia, Dahuria, ad fl. Argun, N. Turczaninov s.n. (GOET!, P06810932!); Russia, in montosis ad fl. Argun, 1831, s. coll., s.n. (K!, LE01012790!, MW0049851!); Russia, in montosis Dahuriae ad fl. Argun, 1831, s. coll., s.n. (LE01012785!, LE01012788!); China, in Dahuriae Chinensi, ad fl. Argunum, 1830-1831, N. Turczaninov s.n. (LE01012784!, LE01012789!). - Note: the specimen designated as lectotype is from Trautvetter's herbarium, so it is certainly an original. It matches all characters given in the protologue as it is provided with leaves, nuts and young male catkins. The epithet heterophylla was validly published before in Corylus as a variety of C. avellana, but it was used for a cultivar with deeply incised leaves (now 'Urticifolia'). However, as neither Trautvetter nor Fischer dealt with a cultivar, but with a Siberian wild species, their name is not to be treated as a new combination (Art. 41.4, McNeill et al. 2012). Ledebour cited the protologue of $C$. heterophylla in total under his new name $C$. avellana var. davurica. As he included the type of $C$. heterophylla, his name would be superfluous, but the combination to be adopted was not available due to C. avellana var. heterophylla Loudon (1838). Therefore, C. avellana var. davurica Ledeb. is to be regarded as a nom. nov.

\section{0a. Corylus heterophylla Fisch. ex. Trautv. var. heterophylla}

Note: Corylus heterophylla var. heterophylla was recognized in the Flora of China (Li \& Skvortsov 1999), Flora of the USSR (Bobrov 1936a), the World Checklist and Bibliography of Fagales (Govaerts \& Frodin 1998), and in the Flora Sichuanica (Editorial Board of the Flora Sichuanica 2012), although in the latter, they were regarded as distinct taxa: C. kweichowensis var. kweichowensis and C. kweichowensis var. sutchuensis.

C. mongolica Burchardt, Verhandlungen des Vereins zu Beförderung des Gartenbaues in den Königlich Preußischen Staaten 9: 108 (Burchardt 1833) nom. inval. (name not fully accepted). - C. mongolica K.Koch, Dendrologie; Bäume, Sträucher und Halbsträucher, welche in Mittel- und Nord-Europa im Freien kultivirt werden 2 (2): 13 (Koch 1873) nom. inval. pro syn. - Note: Theodor Heinrich Otto Burchardt (13 Dec. 1771-6 Feb. 1853, Müller 1861) reported that he obtained nuts from "Herr von Hartwitz" [N.A. von Hartwiss] from Nikita, Crimea, who got his material from F.E.L. Fischer from St. Petersburg for cultivation. Burchardt mentioned in the protologue that he sowed the largest ones in 1829, but none of them germinated. However, Burchardt emphasized that the nuts were flattened at their tips, which is typical for what is nowadays referred to as C. heterophylla. Fischer had the newly collected Central Asian material of C.F. von Ledebour and Turczaninov at hand, and 
apparently also in cultivation in the St. Petersburg Botanical Garden. As there is only one species known from that area, C. heterophylla, and it has flattened nuts, Burchardt's C. mongolica is an earlier name of $C$. heterophylla. However, Burchardt expressed some doubt: "Höchst wahrscheinlich werden wir aber die Corylus-Arten durch eine neue species, mit der Corylus mongolica vermehren müssen." [Most likely, we will have to increase the number of Corylus species by a new species, Corylus mongolica]. Due to the explicit doubt expressed, the name does not need to be considered (Art. 36, McNeill et al. 2012).

C. hasibami Siebold, Annuaire de la Société Royale pour l'Encouragement de l'Horticulture dans les Pays-Bas: 27 (Siebold 1844) nom. nud. - Note: the material of this nom. nud. was introduced in Leiden Botanical Garden from material from P.F. von Siebold in 1829. Two years after publishing this name, Siebold himself synonymized the name under C. heterophylla (Siebold \& Zuccarini 1846), while Blume (1851: 310) synonymized it under his new C. heterophylla var. thunbergii.

C. heterophylla var. thunbergii Blume, Museum Botanicum Lugduno-Batavum 1: 310 (Blume 1851) ["1849-1852"]. - C. thunbergii (Blume) K.Koch, Dendrologie; Bäume, Sträucher und Halbsträucher, welche in Mittel- und Nord-Europa im Freien kultivirt werden 2 (2): 13 (Koch 1873). - Original citation: "In Japoniâ." - Original material: Japan, e Japonia, C.P. Thunberg s.n. (UPS-THUNB 22494!); Japan [without locality], H. Bürger s.n. (M-0153659!, M-0153660!, M-0153661!). Original material?: Japan, Japonia, s. coll., s.n. (K00859904!).

C. heterophylla var. japonica Koidz., The Botanical Magazine [Tokyo] 27: 143 (Koidzumi 1913). Original citation: "Japonia." - Type: not localized.

C. heterophylla var. yezoensis Koidz., The Botanical Magazine [Tokyo] 27: 143 (Koidzumi 1913). C. yezoensis (Koidz.) Nakai (nom. inval. pro syn.), Flora Sylvatica Koreana 2: 9 (Nakai 1915). Orinial citation: "Yezo: Prov. Isikari, prope Sapporo."-Type: not localized. - Note: Corylus yezoensis is regarded as a synonym of C. heterophylla var. thunbergii in the Flora of Japan (Ohwi 1965) and the World Checklist and Bibliography of Fagales (Govaerts \& Frodin 1998), where that variety is treated as a distinct variety.

C. heterophylla var. shenyangensis L.Zhao \& D.Chen, Flora Liaoningica 1: 1361 (Zhao \& Chen 1988).Type: China, Liaoning, Shenyang shi, L. Zhao [赵冷] 591 (holo-: IFP03404001a0001). - Note: the herbarium where the type is deposited was incorrectly given as "FPI" in the protologue.

C. retusa Siebold \& Zucc. nom. nud. in sched. - Note: this name solely appears on some specimens collected by Siebold (BR!, K000859905!, M-0153658!).

10b. Corylus heterophylla var. sutchuenensis Franch.

Journal de Botanique (Morot) 13: 199 (Franchet 1899). - C. sutchuensis (Franch.) Nakai, Journal of Japanese Botany 15 (9): 524 (Nakai 1939). - C. kweichowensis var. sutchuenensis (Franch.) C.C.Yang, Flora Sichuanica 21: 5 (Editorial Board of the Flora Sichuanica 2012) nom. illegit. superfl. - Type: China, Sichuan, Tchen keou tin, 1400 m a.s.l., P.G. Farges 805 [originally cited "809"] (lecto-, designated here: P06810915!; isolecto-: B!, B!, P06810916!, P06810917!). - Note: Corylus heterophylla var. sutchuenensis was recognized in the Flora of China (Li \& Skvortsov 1999) and the World Checklist and Bibliography of Fagales (Govaerts \& Frodin 1998) while it was regarded as a variety of a distinct C. kweichowensis in the Flora Sichuanica (Editorial Board of the Flora Sichuanica 2012).

C. heterophylla var. crista-galli Burkill, The Journal of the Linnean Society. Botany 26: 504 (Burkill 1899). - Type: China, Hunan, Shimên, Mar. 1886, A. Henry 7942 (lecto-, designated here: K000859899!). - Additional type material: China, Hubei, Patung, Sep. 1886, A. Henry 1449 (syn-: K000859898!, K000859900!, K000859903!, P06809382!); China, Hubei, Ichang, Feb. 1887, A. Henry 2854 (syn-: K000859903!); China, Hubei, Ichang, Feb. 1887, A. Henry 2866 (syn-: K000859900!); China, Hubei, Tungku, Mar. 1889, A. Henry 6413 (syn-: BM!, GH00033780, K000859901!, K000859902!, P06809384!); China, Yunnan, "gorges of Lanho near Lankong”, 7 
Aug. 1883, J.M. Delavay 128 (syn-: P06810940!). - Additional original material: China, Yunnan, les bois à Yang in Chang près de Lankong, 7 Aug. 1883, J.M. Delavay 128 (K!, P06810941!). Note: this variety is mainly characterized by the long glandular trichomes especially on the petioles. Specimens of Delavay bearing the Delavay's original number 128 (see Holstein \& Weigend 2016a) were likely collected at different localities. Burkill, however, only cited one of these gatherings, being "gorges of Lanho near Lankong". The collections from "les bois à Yang in Chan près Lankong" from the same date (K!, P06810941!) are not syntypes, but may be regarded as original material. However, they differ in being somewhat tomentose and lacking glandular trichomes on the petioles and the lower leaf lamina, linking to C. yunnanensis. The specimen chosen as a lectotype here shows the double-serrate bract margin as a name-giving character for this taxon, as well as the young male catkins that typically develop in $C$. heterophylla as the fruits mature.

C. kweichowensis Hu, Bulletin of the Fan Memorial Institute of Biology n.s., 1: 149 (Hu 1948). - Type: China, Kweichow [Guizhou], Ichaipa, Longli County [龙里县], 6 Jul. 1930, Y. Tsiang [蒋英] 8441 (lecto-, designated here: PE00021973!; isolecto-: PE00734547!). - Note: the collection number 8411 in the protologue is mistaken, because Y. Tsiang 8411 is a species of Pyrus, conversely Y. Tsiang 8441 is a Corylus and matches the other collection data from the protologue. Corylus kweichowensis is regarded by Liang (1988) as a distinct species (with a distinct $C$. heterophylla var. sutchuensis) and treated as such in the Flora Sichuanica (Editorial Board of the Flora Sichuanica 2012).

C. kweichowensis var. brevipes W.J.Liang, Bulletin of Botanical Research. Harbin 8 (4): 117 (Liang 1988). - Type: China, Jiangxi, 990 m a.s.1., 18 Sep. 1984, W.J. Liang 84001 (holo-: IFP03404999za001!).

\section{Corylus jacquemontii Decne.}

Voyage dans l'Inde 4: 160 (Jacquemont 1844). - C. colurna var.jacquemontii (Decne.)A.DC., Prodromus Systematis Naturalis Regni Vegetabilis 16 (2): 130 (Candolle 1864). - Original citation: "Frequens à Vernague ad jugum Banhatte; alt. 2952 m." - Type: Laos, inter Vernag. et Ban Hatte, V. Jacquemont 784 (lecto-, designated here: P06811323!; isolecto-: P06811322!).

C. colurna var. lacera A.DC., Prodromus Systematis Naturalis Regni Vegetabilis 16 (2): 131 (Candolle 1864). - Type: India, [Uttarakhand], Kumaon, R. Blinkworth in Wallich Catalogue no. 2798 (syn-: not localized; isosyn-: BM001191574!, K000859891!, K001117112!).

\section{Corylus maxima Mill.}

The Gardeners Dictionary ed. 8 no. 2 (Miller 1768). - C. tubulosa Willd., Species Plantarum ed. 4 4 (1): 470 (Willdenow 1805) nom. illegit. superfl. - C. avellana var. tubulosa Loudon, Arboretum et Fruticetum Britannicum 3: 2018, fig. 1943 (Loudon 1838). - Original citation: Only a reference to Bauhin (1623: 418): "Corylus sativa fructu oblongo," which does not contain figures. - Type: not localized (No original specimen found in BM or K). - Note: Corylus maxima was recognized in the Flora of the USSR (Bobrov 1936a), Flora Europaea and World Checklist and Bibliography of Fagales (Govaerts \& Frodin 1998). The absence of both a physical specimen and the direct citation of an illustration (Art. 7.7, McNeill et al. 2012) makes the interpretation of this name difficult. The rather cryptic description of the stipules being intermediate between C. avellana and C. colurna makes it rather hard to understand the exact intention of the author. Miller wrote that "red and white Filberts, both which are so well known, as need no description" (and was definitely wrong in that point). Solely his citation of Bauhin's descriptive name "Corylus sativa fructu oblongo," gives some indication of what was meant, but the most important character, the involucre of the nut, is not described by him. Miller's idea of C. maxima is clearly connected to the filbert. The word is said to be either derived from "full beard" (Loudon 1838; Goeschke 1887) or from an old English name (Loudon 1838). There are two Saints of the name Philibert: Philibert of Jumièges, whose feast day is 
on $20^{\text {th }}$ August, and Philibert of Toledo, whose feast day is on $22^{\text {nd }}$ August (The Benedictine Monks of St. Augustine's Abbey, Ramsgate 1921), both at the time when filberts are supposed to ripen (Bunyard 1920). Filberts are generally regarded as having a long involucre, much exceeding the ripe nut in length. However, there are two morphs: 1) the involucre is often deeply split and the lobes are striate to reticulate and often bend outwards, and 2) a smooth tubular involucre enclosing the nut and producing a short beak with a laciniate apex, similar to what is found in C. chinensis. Brookshaw (1812, pl. 73) illustrates both kinds, the former as "Barcelona filbert" (also with an oblong nut) and the latter as "white and scarlet filbert." The citations under Bauhin's descriptive name all mention that Miller's "filbert" is cultivated and that the fruit is oblong and is either white or red. White and red filberts were described separately as $C$. avellana var. alba Aiton and C. avellana var. rubra Aiton later-on, so Miller's species includes different entities. The name C. tubulosa is superfluous, because Willdenow cited $C$. maxima in synonymy. Loudon accepted a hazel with a tubular involucre as a distinct and cited $C$. maxima and $C$. tubulosa as synonyms, though he adopted the later name. Since Loudon cited C. maxima Mill. fully, C. avellana var. tubulosa is to be interpreted as nomen novum. As there are no types of C. maxima, C. avellana var. tubulosa is not homotypic (illegitimate) with Aiton's varieties $C$. avellana var. alba and $C$. avellana var. rubra. However, even Loudon did not have a clear image of C. maxima, as Loudon's figure does not correspond to Willdenow's specimens of C. tubulosa (B-W 17704-010!, B-W 17704-020!, B-W 17704-030!).

C. avellana var. sativa C.F.Ludw., Die Neuere Wilde Baumzucht: 14 (Ludwig 1783) nom. nud.

C. avellana var. alba Aiton, Hortus Kewensis 3: 363 (Aiton 1789). - C. alba (Aiton) Steud., Nomenclator Botanicus ed. 2 1: 424 (Steudel 1840). - C. maxima var. alba (Aiton) C.K.Schneid., Illustriertes Handbuch der Laubholzkunde 1: 149 (Schneider 1904). - Original citation: "Corylus sativa fructu albo minore sive vulgaris" (Bauhin 1623). - Type: not localized. - Note: this name is only accompanied with the English common name, so it lacks a description itself, but it contains a validating description by Bauhin (1623; Art. 7.7, McNeill et al. 2012). As there are no corresponding specimens in either Kew or BM, nor a figure in Bauhin's Pinax Theatri Botanici, there is no original material. The citations under the name "Corylus sativa fructu albo minore sive vulgaris" are ambiguous. They sometimes mention a round nut in contrast to the oblong nut typical of the filbert. This is in contrast to the citation of Dodoens' C. hortensis (Dodoens 1757: 515), to whom Bauhin also referred. Dodoens differentiates and illustrates two hazels, a wild one (a mirror image copy from Fuchs (1542: 398), which is the lectotype of C. avellana L.), and the domesticated one (Fuchs 1542: 399). Dodoens' cultivated hazel has a laciniate involucre, and he explicitly mentions the red pellicule (testa) of the nut. Bauhin also cites Fuchs' Avellana domestica, although Fuchs clearly states "rubra membrana inclusus", which appears to be in contrast to the "white" fruit of Bauhin's name.

C. avellana var. rubra Aiton, Hortus Kewensis 3:363 (Aiton 1789). - C. rubra (Aiton) Borkh., Theoretisch Praktisches Handbuch der Forstbotanik 1: 723 (Borkhausen 1800) nom. illegit. superfl. - C. maxima var. rubra (Aiton) C.K.Schneid., Illustriertes Handbuch der Laubholzkunde 1: 149 (Schneider 1904). - C. maxima var. rubra f. normalis (Aiton) C.K.Schneid., Illustriertes Handbuch der Laubholzkunde 1: 149 (Schneider 1904) nom. inval. (Art. 24.3, McNeill et al. 2012). - Original citation: "Corylus sativa fructu oblongo rubente" (Bauhin 1623: 418). - Type: not localized. - Note: as for C. avellana var. alba, C. avellana var. rubra is only accompanied with the English native name, but it contains a validating description by Bauhin (Art. 7.7, McNeill et al. 2012). As there are no corresponding specimens in either Kew or BM, nor a figure in Bauhin's Pinax Theatri Botanici, there is no original material. According to Bauhin's phrase name, this taxon has oblong reddish nuts, corresponding to the red filbert of Miller (1768). Rea (1665) already described the "wellknown" filberts and indicates that the "red filbert" has a red testa, but he did not mention red leaves, although he discussed leaf characters for other names. Also Dodoens (1757: 515) mentioned a red pellicule. Therefore, the mention of the red color is thus not referring to the foliage, but the testa. The application and interpretation of Borkhausen's C. rubra is confusing in this context, because 
the same descriptive epithet was published before, but it was eventually used to describe something different. In all cases, the authors deal with filberts (in the sense of $C$. maxima Mill.) as they refer to the same Pre-Linnean polynomina by Bauhin. However, on the one hand, the epithet in C. avellana var. rubra Aiton (1789: 363) describes the red testa. On the other hand, Borkhausen understood the epithet to describe a plant with red or brownish leaves, while Aiton did not mention the leaves at all. A red-leaved filbert was mentioned by Du Roi (1771: 178) for the first time, but without giving it a valid name. When Du Roi dealt with Miller's Corylus maxima, he distinguished white filberts and red filberts as did Miller and later Aiton; he even cited the same polynomina by Bauhin. But in contrast to Miller and Aiton (and any other author to our knowledge), already Du Roi understood his "red filberts" to have red or brownish leaves. Since there is no information on the leaf color of Miller's and Aiton's "red filbert", it is doubtful whether Borkhausen actually meant his name to be something new. Even Goeschke (1887) mentions that the "Rote Lambertsnuss"/red filbert has slightly brownish leaves, while he accepted a purple-leaved filbert as something different. Corylus rubra is therefore interpreted best a new combination, because Borkhausen meant the same "red filbert" that also Miller and Aiton cited by using Bauhin's polynomen, although Aiton and Borkhausen referred the epithet to different characters. Since Borkhausen does not discuss green-leaved filberts or cited any filberts under another name, there is no apparent intent to describe a new species but rather to use a better-fitting name. Therefore, Art. 41.4 (McNeill et al. 2012) applies. However, Borkhausen's new combination is illegitimate, as he also cites a "Corylus maxima Münch.." in synonymy. The present authors are not aware of any publication of this name, but rather interpret this name as an "updated" citation. Münchhausen does not use Miller's binomial in the third volume of his Der Hausvater (Münchhausen 1768: 827), but refers to Miller's polynomen (Miller 1759) that Miller took up later. Münchhausen also did not publish that name when he dealt with hazelnuts again in the fifth volume of the Der Hausvater (Münchhausen 1770: 142). He omitted the discussion of the filberts at all by referring to his publication in the third Hausvater volume. After Miller adopted the binomials in the eigth edition of his The Gardeners Dictionary and published C. maxima (Miller 1768), Borkhausen apparently updated Münchhausen's description (who also did not mention red leaves). Nevertheless, Borkhausen makes an indirect reference to a published name on the same rank without excluding parts of it, rendering his C. rubra superfluous.

C. tubulosa var. oblonga Risso, Histoire Naturelle des Principales Productions de l'Europe Méridionale et particulièrement de Celles des Environs de Nice et des Alpes Maritimes 2: 332 (Risso 1826). Type: not localized.

C. intermedia Fingerh., Linnaea 4: 384, tab. III fig. 4 (Fingerhuth 1829). - Original citation: "Wächst an schattigen Stellen bei Esch im Köllner Regierungs-Bezirk." - Type: not localized.

C. sativa Poit. \& Turpin, Pomologie Française Recueil des Plus Beaux Fruits Cultivés en France 4: tab.11 (Poiteau 1846) nom. illegit. superfl. - Note: this name was published with C. tubulosa Willd. as a synonym. The plate also depicts the kind of hazel that is here considered to represent C. maxima. Poiteau and Turpin even show the dark red testa that was mentioned in literature cited by Bauhin on which C. maxima relies upon.

C. avellana var. viminalis Henriksson, Botaniska Notiser 1918 (6): 297 (Henriksson 1918). - Type: Sweden, Dalia, paroecia Gunnarsnäs, in silva Hällan ad Mörtviken, J. Henriksson s.n. (holo-: not localized).

\section{2a. Corylus maxima 'Purpurea'}

C. avellana var. purpurea hort. ex Loudon, Arboretum et Fruticetum Britannicum 3: 2017 (Loudon 1838). - C. tubulosa [unranked] purpurea Audib. ex Mouill., Traité des Arbres \& Arbrisseaux 2: 1142 (Mouillefert 1891-1898) nom. illegit. superfl. - C. maxima var. purpurea (hort. ex Loudon) Rehder, Manual of Cultivated Trees and Shrubs Hardy in North America: 154 (Rehder 1927). C. maxima (var. rubra) f. purpurea (hort. ex Loudon) C.K.Schneid., Illustriertes Handbuch der 
Laubholzkunde 1: 149 (Schneider 1904). - C. maxima f. purpurea (hort. ex Loudon) Rehder, Bibliography of Cultivated Trees and Shrubs Hardy in the Cooler Temperate Regions of the Northern Hemisphere: 111 (Rehder 1949). - C. purpurea A.DC., Prodromus Systematis Naturalis Regni Vegetabilis 16(2): 132 (Candolle 1864) nom. inval. pro syn. - C. atropurpurea hort. ex Loudon, Arboretum et Fruticetum Britannicum 3: 2017 (Loudon 1838) nom. inval. pro syn. C. atropurpurea Booth et al., James Booth \& Söhne, Eigenthümer der Flottbecker Baumschulen bei Hamburg 1845: 45 (Booth et al. 1845).- C. avellana var. atropurpurea (Booth et al.) G.Kirchn., Arboretum Muscaviense: 670 (Petzold \& Kirchner 1864). - C. tubulosa var. atropurpurea (Booth et al.) A.DC., Prodromus Systematis Naturalis Regni Vegetabilis 16(2): 132 (Candolle 1864). C. maxima f. atropurpurea (Booth et al.) Dippel, Handbuch der Laubholzkunde 2: 130 (Dippel 1891) ["1892"]. - Type: not localized. - Note: this is a cultivar with dark red to purple leaves, but Loudon did not give any information on the involucre or the shape of the nut necessary for the differentiation between $C$. avellana and C. maxima. More complicating, Loudon did not differentiate between C. avellana and C. maxima at a species level. Loudon cited Loddiges' Catalogue of Plants ed. 16 (Loddiges 1836) as only source. Original material therefore came from commercial cultivation, and there is no physical material to our knowledge. Goeschke (1887: 79) reported that his "Rotblättrige Lambertsnuss" ("red-leaved Lambert's hazel or Filbert") was introduced as "Corylus atropurpurea" by the Pépinières Baumann in Bollwiller, Alsace, France in the 1820s. Loudon cited just this name (in synonymy to purpurea), and it is therefore likely that Goeschke had the original cultivar in mind in his book. According to Goeschke's description, this cultivar has purple leaves, a smooth tubular involucre, and the nut has a pale pink testa. This cultivar still exists under the name 'Purple Aveline'. Red/purple foliage is apparently of a single origin in Corylus. Thompson (1985) reported that the locus for leaf coloration (A for anthocyanin) and the self-incompatibility "gene" were linked in Corylus, which is confirmed by Ives et al. (2014). The cultivars 'Fuscorubra' and 'Rode Zeller' have the S6 allele, while 'Purple Aveline' (Rotblättrige Lambertsnuss/C. atropurpurea hort./C. maxima 'Purpurea') has the alleles S5S10. The cultivar 'Fuscorubra' has a short bract husk, while 'Rode Zeller' has a long husk. In 'Rode Zeller', however, the husk is not long tubular, but the bract lamina is striate and presents the nut openly in contrast to C. maxima 'Purpurea'. Both cultivars inherit the red leaf coloration (Thompson et al. 1996), while C. maxima 'Purpurea'/'Purple Aveline' does not and is thus interpreted as graft hybrid on 'White Aveline', which is C. maxima/C. avellana var. alba. As Loudon cited the horticultural epithet atropurpurea in synonymy, it is a pro synonym of purpurea. As a horticultural variety (cultivar) it is best called C. maxima 'Purpurea', since this epithet is the oldest, unambiguously referable name to the cultivated plant (Art. 29.1, Brickell et al. 2009). However, it must be noted that the name "C. maxima" has been widely misapplied to a largeand round-fruited cultivar of $C$. avellana, and it was even validly published as C. avellana var. maxima for just that round-fruited cultivar. Bean's C. maxima var. atropurpurea (Bean 1898: 350) is such a case, and the described plant likely refers to a cultivar similar to 'Rode Zeller'.

\section{Corylus potaninii Bobrov}

Sovietskaia Botanica 1936 (1): 29, fig. 3 (Bobrov 1936b). - Original citation: "Hab. China, prov. Sutchuen, Ta-chien-lu, s. Datzzien-lu, tibetice Tarsando, 26 VI 1893; 1 VII 1893 (typus) G.N. Potanin legit; ut videtur in prov. Hupeh, Yunnan et Kweichow crescit." - Type: not localized. - Note: it is unclear from the protologue whether $C$. potaninii is intended as a new species or a nom. nov. On the one hand, Bobrov cited C. heterophylla var. sutchuensis and C. heterophylla var. crista-galli just after the new name in the protologue. However, he did not formally synonymize or accept these names anywhere else, so they might be regarded as synonyms of his new name. However, Bobrov expressedly distinguished his new species from these varieties later-on. Therefore, C. potaninii is best considered as intended as a new species. Corylus potaninii is supposed to be similar to C. heterophylla var. sutchuensis, but differing in rounded leaves and densely pubescent lower leaf 
laminae and young twigs. Bobrov also mentioned similarities to C. heterophylla var. crista-galli most likely referring to the long-stalked glandular trichomes. Long-stalked glandular trichomes are also found on an isolectotype specimen of C. heterophylla var. yunnanensis (P06810939), therefore either the type material is mixed or taxon delimitation is obscure. Corylus potaninii was recognized by World Checklist and Bibliography of Fagales (Govaerts \& Frodin 1998), but not even mentioned in the Flora of China (Li \& Skvortsov 1999) or in the Flora Sichuanica (Editorial Board of the Flora Sichuanica 2012).

\section{Corylus sieboldiana Blume}

Museum Botanicum Lugduno-Batavum 1: 310 (Blume 1851) [“1849-1852"]. - C. heterophylla var. sieboldiana (Blume) A.DC., Prodromus Systematis Naturalis Regni Vegetabilis 16 (2): 130 (Candolle 1864). - C. rostrata var. sieboldiana (Blume) Maxim., Bulletin de l'Académie Impériale des Sciences de St.-Pétersbourg 27: 538 (Maximowicz 1881). - Original citation: "Siki-fasibami s. Tsumo-fasibami japonice. Sponte in japonice montibus Nikoo fide speciminis Herb. von Siebold." Type: Japan, [locality unknown], P.F. von Siebold. 2 or 16 (lecto-, designated here: upper plant of L0366714!). - Additional type material: Japan, [unclear locality], P.F. von Siebold. 2 or 16 (syn-: lower plant of L0366714!). - Note: there are actually two collections on the sheet, the upper one with fruits and a lower one without. There are four labels on the specimen. A first label is attached to the upper specimen containing the Japanese name in Katagana signs シ[shi]キ[ki]ハ[ha]シ[shi]ハ[ha, also to be pronounced as ba] ミ [mi], literally "lucky hazel". A second label is a Leiden label with the Latin name C. sieboldiana and transcription of the Japanese name "Si-ki-hasi-bami". A third label is Siebold's original in the lower left with the number 16 and the Japanese name in Katagana signs ツ[tsu]ノ[no]ハ[ha]シ[shi]ハ[ha, also to be pronounced as ba]ミ[mi], literally "horned hazel". The fourth label bears the number 2, locality as in the protologue, and the Latin and the Japanese name. It is unclear which label with a number corresponds to which specimen or where the "no. 2" comes from, therefore the lectotype citation here is given rather crudely. The " $\mathrm{f}$ " in the transcriptions in the protologue is easily explained as misreading of the " $\mathrm{h}$ " of the original label in the Kurrent handwriting, which is similar to the " $\mathrm{f}$ ". The indument of the tubular involucre varies among the different type specimens of the synonyms. Two basic forms can be found in different described varieties of $C$. sieboldiana. The involucre is glabrous or very finely hairy $(C$. sieboldiana var. mitis and $C$. hallaisanensis), while it consists of dense bristly trichomes in C. sieboldiana var. brevirostris, C. sieboldiana var. mandshurica, and C. sieboldiana var. sieboldiana. The type of $C$. hallaisanensis differs from C. sieboldiana var. mitis in having apically coarsely irregular serrated leaves, like C. sieboldiana var. mandshurica. To the present authors' knowledge, there is no critical revision or phylogeographic analysis existing that has tested the significance of the involucre indument.

\section{4a. Corylus sieboldiana Blume var. sieboldiana}

C. rostrata var. mitis Maxim., Bulletin de l'Académie Impériale des Sciences de St.-Pétersbourg 27: 539 (Maximowicz 1881). - C. sieboldiana var. mitis (Maxim.) Nakai, Flora Sylvatica Koreana 2: 13 (Nakai 1915). - Original citation: "Japonia. Nippon. Fudzi yama." - Type: Japan, Fudji yama, 1864, S. Tschonoski s.n. (holo-: LE; iso-: BM!, BR!, GH00033783!, K000859897! K000859896!, P06810985!). - Note: Corylus rostrata var. mitis was regarded as synonymous to C. sieboldiana in the Flora of Japan (Ohwi 1965) and the World Checklist and Bibliography of Fagales (Govaerts \& Frodin 1998).

C. sieboldiana var. brevirostris C.K.Schneid., Plantae Wilsonianae 2: 453 (Sargent 1916). C. brevirostris (C.K.Schneid.) Miyabe, Journal of the Faculty of Agriculture, Hokkaido University 26: 458 (Miyabe \& Kudo 1934). - Type: Japan, Hokkaido, Shiribeshi-san, 700 m a.s.1., 27 Jul. 1914, E.H. Wilson 7268 (holo-: A00033784!). - Additional type material: Japan, Hakodate, 1861, 
C. Maximowicz s.n. (para-: BM!); Japan, Northern Honshū, prov. Mutsu, Hakkoda Mountain, Aug. 1904, U. Faurie 5803 (para-: BM!, E00020189!). - Note: Corylus brevirostris was recognized as a separate species by World Checklist and Bibliography of Fagales (Govaerts \& Frodin 1998), while it is recognized as C. sieboldiana var. brevirostris in the Flora of Japan (Ohwi 1965).

C. hallaisanensis Nakai, Repertorium Specierum Novarum Regni Vegetabilis 13: 250 (Nakai 1914). Original citation: "Quelpaert: in silvis Hallaisan." - Type: Korea, Hallasan Mountain, Oct. 1907, E.J. Taquet 333 (syn-: not localized; isosyn-: E00020176!, TI); ibid., 12 Jun. 1913, T. Nakai 335 (syn-: not localized); ibid., 17 May 1913, T. Nakai 930 (syn-: not localized). - Note: Corylus hallaisanensis was recognized as separate species in the World Checklist and Bibliography of Fagales (Govaerts \& Frodin 1998). Chang et al. (2004) suggested synonymizing this name to be under C. sieboldiana, but fail to indicate to which of the two varieties it is supposed to belong (C. sieboldiana var. mandshurica or C. sieboldiana var. sieboldiana).

\section{4b. Corylus sieboldiana var. mandshurica (Maxim.) C.K.Schneid.}

Plantae Wilsonianae 2: 454 (Sargent 1916). - C. rostrata var. mandshurica (Maxim.) Regel, Bulletin de la Classe Physico-Mathématique de l'Académie Impériale des Sciences de Saint-Pétersbourg 15 (14-15): 221 (Regel 1857). -C. mandshurica Maxim., Bulletin de la Classe Physico-Mathématique de l'Académie Impériale des Sciences de Saint-Pétersbourg 15 (8-9): 137 (Maximowicz \& Ruprecht 1856). - Type: Russia, Amur river, C.J. Maximovicz s.n. (lecto-, designated by Bobrov 1936a: 268: LE; isolecto-: M-0265486!, GH00033781!, K000859911!, P06810979!, P06810986!, PE00021985!). - Note: this name was also regarded as a variety in the Flora of Japan (Ohwi 1965), while it was recognized as a distinct species in the Flora of the USSR (Bobrov 1936a), the Flora of China (Li \& Skvortsov 1999), and in the Flora Sichuanica (Editorial Board of the Flora Sichuanica 2012).

C. brevituba Kom., Izvestija Glavnogo Botaniceskogo Sada SSSR [Bulletin du Jardin (Botanique) Principal de l'URSS] 28: 219 (Komarov 1929). - C. mandshurica f. brevituba (Kom.) Kitag., Neolineamenta Florae Manshuricae: 217 (Kitagawa 1979). - Original citation: "Legit O.O. Kuzeneva 12 VIII 1926 in provincia Amurensi ad ripas fl. Tomj (fl. zea influentis), in decursu superiore ejus ad pedem montium Burejensium: № 520 et 523. In declvi silvoso ad fontem." - Type: Amur area, basin of the Zeya River, the Tom' River, upper course, offsets of Bureinskii Range, slope at the source of spring, 12 Aug. 1926, O.O. Kuzeneva 523 (lecto-, designated here: LE!). - Note: Corylus brevituba was recognized as separate species by Flora of the USSR (Bobrov 1936a), although it is noted that is scarcely different from C. mandshurica. The lectotype was placed to LE (Bobrov 1936a: 268), but without mentioning a specific specimen.

C. mandshurica f. glandulosa S.L.Tung, Bulletin of Botanical Research. Harbin 1 (1-2): 138 (Tung 1981). - Type: China, Heilongiiang Province, Shangzhi Country, 2 Aug. 1956, Y.L. Chou [周以良] 3902 (holo-: NEFI). - Additional type material: China, Jilin Province, Linjiang Country, 1 Jul. 1962, P.H. Huang [黄普华] et al. 60222 (para-: not localized); China, Heilongjiang Province, Jingpo Lake, [Mudanjiang Team] 129 (para-: not localized).

\section{Corylus wangii $\mathrm{Hu}$}

Bulletin of the Fan Memorial Institute of Biology, Botany 8: 31 (Hu 1937). - Type: China, Yunnan, Weisi Hsein, Yeh-Chih, 3400 m a.s.l., Aug. 1935, C.W. Wang 68243 (lecto-, designated by Lin et al. 2007: 1249: PE01062681!; isolecto-: A00033785!, K000859895!, P01903232!, PE01062680!). Note: Corylus wangii was recognized in the Flora of China (Li \& Skvortsov 1999) and the World Checklist and Bibliography of Fagales (Govaerts \& Frodin 1998). Hu (1948: 149), on the other hand, regarded his species as synonymous to $C$. jacquemontii Decne. However, C. wangii has an involucre with many glandular trichomes, while $C$. jaquemontii is eglandular. Both $C$. jacquemontii 
and $C$. wangii have long laciniate involucre apices, but these are sometimes divided in the latter. This latter character is very well developed in C. ferox. The involucre of $C$. wangii are thus strikingly similar to $C . \times$ spinescens Rehder, an artificial hybrid between C. ferox var. tibetica and C. avellana.

\section{Corylus wulingensis Q.X.Liu \& C.M.Zhang}

Bulletin of Botanical Research. Harbin 10 (1): 35 (Liu \& Zhang 1990). - Type: China, Hunan, Shauangzh Xian Badagungshan Yochang, 1450 m a.s.l., Aug. 1988, C.M. Zhang [张灿明] 8808185 (“typus in Herb. Inst. Sylv. Hunan Conservatur"). - Note: Corylus wulingensis was recognized by the World Checklist and Bibliography of Fagales (Govaerts \& Frodin 1998), but not mentioned in the Flora of China (Li \& Skvortsov 1999). However, according to the protologue and the accompanying figure, this taxon is morphologically intermediate between C. yunnanensis and the type of C. heterophylla var. crista-galli (listed here as a synonym of $C$. heterophylla var. sutchuensis). It shares the dense indumentum with the former, and the occurrence of glandular trichomes and the short involucre with the latter taxon.

\section{Corylus yunnanensis (Franch.) A.Camus}

Bulletin du Muséum National d'Histoire Naturelle ser. 2 1: 438 (Camus 1930) [“1929”]. - C. heterophylla var. yunnanensis Franch., Journal de Botanique (Morot) 13: 198 (Franchet 1899). - Original citation: "China occidentalis, in provincia Yunnan, in silvis prope collum Hee chan men, alt. 3000 m. (R.P. Delavay); in monte Tsang chan (id., n. 555)." - Type: China, Yunnan, Les bois au col de Hee chan men, 3000 m a.s.1., 5 Jul. 1889, J.M. Delavay s.n. (lecto-, designated here: P01903229!; isolecto-: P06810939!, P06811346!). - Additional type material: China, Yunnan, Hee chan men, Feb. 1883, J.M. Delavay s.n. (syn-: P06810993!); China, mt. Tsang chan, S / Tali, 4 Jul. 1882, J.M. Delavay 555 (syn-: P01903230!, P01903231!). - Note: Corylus yunnanensis was recognized in the Flora of China (Li \& Skvortsov 1999), the Flora Sichuanica (Editorial Board of the Flora Sichuanica 2012), and World Checklist and Bibliography of Fagales (Govaerts \& Frodin 1998).

\section{Hybrid names}

C. $\times$ vilmorinii Rehder, Journal of the Arnold Arboretum 7 (2): 146 (Rehder 1926). - Type: USA, Massachusetts, cult. at Arnold Arboretum from material by M.L. de Vilmorin, Sep. 1919 (syn-: not localized); ibid., 18 Aug. 1921, J.G. Jack bis AA7549 (syn-: A00033778); ibid., 7 Apr. 1922 (syn-: not localized); ibid., 23 Sep. 1925 (syn-: not localized). - Note: artificial hybrid of C. avellana and C. chinensis.

C. $\times$ spinescens Rehder, Journal of the Arnold Arboretum 7 (2): 147 (Rehder 1926). - Type: USA, Massachusetts, cult. by Arnold Arboretum from material by M.L. de Vilmorin, 23 Sep. 1925, A. Rehder AA19020 (lecto-, designated here: A00033777!; isolecto-: A00033776!). - Additional type material: USA, Massachusetts, cult. at Arnold Arboretum from material by M.L. de Vilmorin, 6 Mar. 1922, A. Rehder AA19020 (syn-: not localized); ibid., 5 Dec. 1921, A. Rehder AA19020 (syn-: not localized). - Note: Artificial hybrid of $C$. avellana and $C$. tibetica.

\section{Nomina dubia}

C. avellana var. ölandica Fr., Summa Vegetabilium Scandinaviae 1: 55 (Fries 1845) nom. nud.

C. californica G.Kirchn., Arboretum Muscaviense: 671 (Petzold \& Kirchner 1864) nom. nud.

C. mexicana hort. ex G.Kirchn., Arboretum Muscaviense: 672 (Petzold \& Kirchner 1864). - Type: not localized (from cultivation from Königliche Landesbaumschule Sanssouci [Potsdam, Germany]). - 
Note: Petzold and Kirchner received a sapling that is supposed to have come from Mexico. The present authors, however, are not aware of any native species of Corylus from today's Mexico, however, formerly, Mexico included the areas of today's California, Utah, Nevada to Texas. This name could refer to C. cornuta subsp. cornuta or C. cornuta subsp. californica.

C. avellana var. arenata Henriksson nom. nud. in sched. - Associate material: Sweden, Dalia, paroecia Ärtemark, 2 Sep. 1926, J. Henriksson s.n. (LD1782996). - Note: this voucher contains sterile specimens with branches with leaves with retuse apex, which is common in C. heterophylla and C. mandshurica.

C. avellana f. olandica H.J.Andersson nom. nud. in sched. - Associate material: Sweden, Öland, Borgholm, Aug. 1907, H.J. Andersson s.n. (BM!, BM!, LD1328264); Sweden, Borgholms alfvar, Jul. 1896, J. Erikson s.n. (LD1328384).

C. avellana var. silvestris Henriksson nom. nud. in sched. - Associate material: Sweden, Dalia, paroecia Gunnarsnäs in pascuis silvosis ad Hällan, 89 m a.s.l., 10 Sep. 1915, J. Henriksson s.n. (LD1791305).

C. formosana Hayata, General Index to the Flora of Formosa as recorded in all literature up to the publication of Icones Plantarum Formosanarum VI: 72 (Hayata 1917) nom. nud.

C. heteromorpha C.C.Yang nom. nud.? in sched. - Associate material: China, Yunnan, Songming County [嵩明县], 邵甸大竹园乡果东照壁山, sparse woodland, shade, wet slopes, 22 Apr. 1956, B.J. Qiu [邱柄云] 51596 (PE00021981!); ibid., Guǒ dōng [果东], 23 Aug. 1957, B.-J. Qiu [邱柄 云] 54913 (PE00021975!). - Note: Corylus heteromorpha C.C.Yang is listed in Chinese Virtual herbarium as $C$. heleromorpha. The bracts are similar to $C$. jacquemontii, but much shorter, likely only barely surpassing the nuts (fallen out on the specimens). The present authors are not aware of a publication of this name. The seen specimens bear labels by Yang from 1990, and later labels with that name again from 2006.

C. spiculata C.C.Yang nom. nud.? in sched. - Associate material: China, s. loc., Aug. 1911, s. coll., s.n. (N061030513 n.v.); China, Guizhou, Hezhang County [赫章县], Kunming Workstation [昆 明工作站] 1091 (PE00021982!); China, Guizhou, Qingzhen City [清镇市], Dà pō Mountain [ 大坡山], 1150 m a.s.1., 17 Oct. 1956, X.L. Jiang [蒋兴麟] 2124 (PE00021983!); China, Guizhou, Bijie City [毕节市], 二区保合乡, 19 Aug. 1957, P.H. Yu [禹平华] 314 (PE00021978!); China, Guizhou, Hezhang County [赫章县], 财神塘, 1480 m a.s.l., 11 Oct. 1957, P.H. Yu [禹平华] 1291 (PE00021977!). - Note: the present authors are not aware of a publication of this name. The seen specimens bear labels by Yang from 1977, and later labels with that name again from 2006. The involucre is leafy with a double-serrate margin, however, it is much longer than the nut. There are similarities to C. heterophylla var. sutchuensis, where the involucre is about are as long as the nut. However, given the large variability of the involucre length, for example in C. avellana, description of this name should be underpinned by other strong evidence than just the involucre morphology.

\section{Nomina excludenda}

C. virginiana Münchh., Der Hausvater 3: 830 (Münchhausen 1768) nom. utique rejic. (Holstein \& Weigend 2016b; Wilson 2017).

\section{Discussion}

As for Carpinus, Ostrya, and Ostryopsis (Holstein \& Weigend 2016a, 2017), we found many overlooked basionyms (even if Henriksson's names are ignored). Ninety-five basionyms, except for the nomina dubia 
and excludenda, but including illegitimate and invalid names as far as unambiguously assignable to a valid name were not listed before. The nescience (and rediscovery) of older names, such as C. avellana var. microphylla Lej., C. avellana f. peltata Buser, and C. avellana f. monstrosa Henriksson rendered later names illegitimate. Although not of significant consequence in Corylus, old names might pose a threat to the stability of currently used names. Corylus mongolica Burchardt might have challenged the well-established $C$. heterophylla for priority if Burchardt had accepted his species fully. Furthermore, some epithets were used on species rank and infraspecific rank despite being based on different types, but not illegitimate according to Art. 53.4 (McNeill et al. 2012). Corylus avellana var. heterophylla Loudon (1838) and C. heterophylla Fisch. ex Trautv. (Trautvetter 1844) and C. avellana var. tenuis Loudon (1838) and Korallova's fossil hazel C. tenuis V.V.Korallova (Korallova \& Panova 1971) are quite similar; and the present authors did not find validly published combinations of the older names that would render the later name illegitimate. Although overlooked names caused the creation of a new epithet for an existing taxon that simply would have needed a status change in Ostryopsis (Holstein \& Weigend 2016a) and led to missing four species in a major regional floristic treatment in Carpinus (Holstein \& Weigend 2017), the consequences in Corylus are minor. But then again, the omission of Corylus potaninii, described from Sichuan, in the Flora of China (Li \& Skvortsov 1999) and the Flora Sichuanica (Editorial Board of the Flora Sichuanica 2012) may be a result of nescience.

The vast majority of heterotypic synonyms is found in C. avellana var. avellana (85) followed by C. colurna (14), both from Europe, while recognition of the major taxa in North America and East Asia is less ambiguous. Many of the taxon definitions go back to characters of the involucre and the shape of the nut and combinations of the two. Thus, Henriksson described 61 legitimate subspecific taxa (plus several illegitimate and invalid names) of $C$. avellana to record all differences found in Scandinavian hazels. While his taxa are hardly of taxonomic value, he 1) followed the early $20^{\text {th }}$ century fashion of splitting, and 2) nicely documented the variability of fruit and involucre characters in what today is treated as a single species without hesitation.

One pervasive problem, especially in the horticultural varieties, is their large-scale negligence in botanical collections and especially herbaria. Few of the varieties have any herbarium vouchers associated, making their unequivocal identification highly problematic especially if, as in much of the older literature, neither detailed descriptions nor illustrations are provided. This is a problem that not only affects Corylus systematics. There is generally an under-documentation of wide-spread and cultivated plants (A. Rockinger (M), F. Luebert (BONN), pers. com.), with C. maxima, a species widely recognized in floras, but only known from cultivation, being a particularly striking example. The observation that Hedera helix L. (Linnaeus 1753: 202), a wide-spread cultivated and feral climber, had not been documented for more than 50 years in the vast herbarium of the Botanische Staatssammlung München (F. Schuhwerk, pers. com.) is a point in case.

While the existence of four major groups in Corylus (Whitcher \& Wen 2001; Forest et al. 2005; Li 2008; Grimm \& Renner 2013) is barely in debate, morphological identification within these groups appears to be more challenging. On the other hand, Bassil et al. (2013) found evidence for genetic separation of only some morphologically hardly distinguishable taxa, for example C. cornuta subsp. californica (vs C. cornuta subsp. cornuta) and C. jacquemontii (vs C. colurna). The latest global taxonomic treatment of Corylus is by Bobrov (1936b), and there has been a major regional update for China (Li \& Skvortsov 1999). Much molecular work has been done, but so far with a focus on cultivars (e.g., Boccacci et al. 2006; Gökirmak et al. 2009; Bassil et al. 2013). The present study attempts to provide the basis for further studies on Corylus phylogeny and taxonomy by providing a detailed list of taxa recognized at one time or another. There are two overall layers to the taxonomic problems, the natural diversity in the wild, which sometimes leads to the recognition of more or fewer species and subspecies across the range of the genus, and the multiplicity of horticultural forms and selections, which have often been treated as 
varieties and subspecies and even species under the ICN in the past. Stable and unequivocal naming of cultivars based on Latin names is going to be much facilitated by the comprehensive list of names here provided. Resolving the remaining taxonomic issues for the wild taxa outside western Eurasia might be relatively straightforward, based on critical herbarium and field studies plus modern, molecular tools.

The clear definition of the cultivated forms, virtually all from western Eurasia, will also find a new basis now, since the clear definition of the wild taxa will help to re-investigate the origins of cultivated forms. There is some overlap between the two, where the identity and origin of cultivated forms remains obscure. The majority of leaf and color variants can be easily assigned to C. avellana in the strict sense, but the large-fruited forms bred for the production of hazelnuts and "filberts" remain highly problematic.

Fruits of Corylus have here been extensively used by humans for at least 10400 years (Holst 2010; Zohary et al. 2012; Antolín \& Jacomet 2015), and there is evidence that they have been traded regionally for at least 4000 years (Fairbairn et al. 2014). They had been domesticated and were widely traded during the Roman empire 2,000 years ago (Pliny the Elder 77-79; Boccacci \& Botta 2009). As active trade and breeding have such a long tradition in Europe and Minor Asia, different morphs and mutations were most likely taken up independently in different regions. Boccacci \& Botta (2009) argue for an independent domestication of $C$. avellana in the western and the eastern Mediterranean, which would imply that the present-day large fruited forms do not have a single, common origin. The fruit-hazels essentially differ in two sets of characters: nut shape (spherical versus elliptical in outline) and involucres (shorter than or equal to the nut, flaring and about twice as long, or much longer and more or less beaked, i.e., contracted above the nut). These characters are more or less freely combined in different varieties. Corylus, and especially the large-fruited forms and the wild C. avellana, have been shown to be fully interfertile except when the parents share self-incompatibility alleles (Erdoğan 1999; Erdoğan \& Mehlenbacher 2000), which must have contributed to some of the diversity observed. However, the large fruited forms do not seem to become naturalized anywhere to any extent, as all national and regional floras clearly emphasize (Bobrov 1936a; Săvulescu 1952), nor is there any clear evidence that wild and domesticated Corylus do hybridize noticeably where they co-occur.

Corylus maxima is a particularly curious case, because the name is widely accepted, but there is neither type material, nor are any wild collections. When Miller described the species, he mentioned that it was so widely known, that a detailed description would be superfluous. Poiteau \& Turpin (Poiteau 1846) mention and illustrate it (under the illegitimate name $C$. sativa), yet, herbarium specimens are unknown. We only found the red-leaved C. maxima 'Purpurea' in herbarium collections, although green-leaved plants are still in cultivation (as 'Aveline Blanche Longue', 'White Filbert', and 'Aveline rouge' or 'Red Filbert'). Many "Corylus maxima" collections, however, are misidentified and might be treated under the name $C$. avellana var. grandis in so far as they have large, but round nuts. The application of formal Latin names for cultivated plants causes a lot of taxonomic uncertainty, i.e., because they tend not to be associated with the documentation usually provided for new species, such as detailed diagnoses and herbarium vouchers. Dochnahl's singular attempt of naming cultivars separate from biological taxa (Greuter \& Holstein 2016) was not a productive effort to resolve this issue. By tracking the sparse evidence from old literature due to absence of type material, we were able to reconstruct the concept behind Miller's C. maxima.

\section{Acknowledgements}

We gratefully acknowledge the great help of the herbarium and literature digitization services, the curators and staff of B, BM, BR, DWC, E, G, GOET, H, K, LE, LIV, M, MANCH, MEL, MO, MSB, MT, and NEU for making the collections available or confirmation of lacking types. Thanks are given to John McNeill and Federico Luebert for discussions on taxonomic problems, Eberhard Fischer for communicating the collections in TBI and Zurab Schewardnadse for help with translations from 
Russian and Georgian, and Tianyun Liu for help with translations from Chinese language. We also thank Genevieve K. Walden, Tilo Henning, and the library staff of B, BM and K for their help to obtain the literature. The reviewers and Alejandro Quintanar Sánchez are thanked for useful comments that helped to improve the manuscript. This research received support (visit to E collection) from the SYNTHESYS Project (http://www.synthesys.info/), which is financed by European Community Research Infrastructure Action under the FP7 "Capacities" Program.

\section{References}

Abrams M.D. \& Nowacki G.J. 2008. Native Americans as active and passive promoters of mast and fruit trees in the eastern USA. The Holocene 18: 1123-1137. https://doi.org/10.1177/0959683608095581

Academia Sinica Kunming Institute of Botany 1991. Flora Yunnanica. Vol. 5. Science Press, Beijing.

Aiton W. 1789. Hortus Kewensis. Vol. 3. Printed for George Nicol, Bookseller to his majesty, Pall Mall, London. https://doi.org/10.5962/bhl.title.4504

Albov N. 1895. Prodromus Florae Colchicae. Tiflis and Genève.

André É. 1879. L'art des Jardins. G. Masson, Paris. https://doi.org/10.5962/bhl.title.105740

Anonymous. 1854. Burchardt's Haselnüsse. Pomona 3 (5-6): 17-19.

Antolín F. \& Jacomet S. 2015. Wild fruit use among early farmers in the Neolithic (5400-2300 cal bc) in the north-east of the Iberian Peninsula: an intensive practice? Vegetation History and Archaeobotany 24 (1): 19-33. https://doi.org/10.1007/s00334-014-0483-x

Audibert U. 1817. Catalogue des Végétaux de tous Genres Cultivés dans les Jardins et Pépinières du Sieur Audibert, Aîné, à Tonelle près Tarascon, département des Bouches-du-Rhone. Élisée Aubanel, Tarascon.

Audibert U. 1831-1832. Catalogue des Arbres, Arbrisseaux, Arbustes, et Plantes. Vol. 2. Seguin aîné, Avignon.

Bassil N., Boccacci P., Botta R., Postman J. \& Mehlenbacher S. 2013. Nuclear and chloroplast microsatellite markers to assess genetic diversity and evolution in hazelnut species, hybrids and cultivars. Genetic Resources and Crop Evolution 60: 543-568. https://doi.org./10.1007/s10722-012-9857-z

Batalin A. 1893. Notae de Plantis Asiaticis XXVIII-XLVIII. Trudy Imperatorskago S.-Peterburgskago botanicheskago sada. Acta Horti Petropolitani 13 (7): 87-106.

Bauhin C. 1623. Pinax Theatri Botanici. Ludovic Regis, Basel. https://doi.org/10.5962/bhl.title.712

Bauhin J., Cherler J.H. \& Chabrey D. 1650. Historia Plantarum Universalis nova et absolutissima cum Consensu et Dissensu circa Eas. Vol. 1. Yverdon. Available from https://books.google.de/books/about?id=0s4_AAAAcAAJ [accessed 22 Jun. 2016].

Bean W.J. 1898. Trees and shrubs. The hazels. The Garden 54: 349-350.

Beck von Mannagetta G. 1890. Flora von Nieder-Österreich. Vol. 1. C. Gerold's Sohn, Wien.

Beissner L. 1903. Kleinere Mitteilungen. Mitteilungen der Deutschen dendrologischen Gesellschaft 12: 126-128.

Beissner L., Schelle E. \& Zabel H. 1903. Handbuch der Laubholzbenennung. Paul Parey, Berlin. Available from https://archive.org/details/Laubholzbenennung1903 [accessed 22 Jun. 2016].

Blume C.L. 1851 [“1849-1852”]. Museum Botanicum Lugduno-Batavum. 1: 305-320. E.J. Bril, Leiden. https://doi.org/10.5962/bhl.title.274 
Bobrov E.G. 1936a. Coryleae. In: Komarov V.L. (ed.) Flora of the U.S.S.R. 5: 253-268. Izdatel'stvo Akademii Nauk SSSR.

Bobrov E.G. 1936b. History and systematics of the genus Corylus. Sovietskaia Botanica 1: 11-39.

Boccacci P. \& Botta R. 2009. Investigating the origin of hazelnut (Corylus avellana L.) cultivars using chloroplast microsatellites. Genetic Resources and Crop Evolution 56 (6): 851-859. https://doi.org/10.1007/s10722-009-9406-6

Boccacci P., Akkak A. \& Botta R. 2006. DNA typing and genetic relations among European hazelnut (Corylus avellana L.) cultivars using microsatellite markers. Genome 49: 598-611. https://doi.org/10.1139/g06-017

Boivin B. 1967. Flora of the Prairie Provinces. Phytologia 16: 329-446.

Booth J. et al. [“James Booth \& Söhne"] 1845. James Booth \& Söhne, Eigenthümer der Flottbecker Baumschulen bei Hamburg.W.L. Anthes, Hamburg.

Borkhausen M.B. 1800. Theoretisch Praktisches Handbuch der Forstbotanik. Heyer, Giessen. Available from https://books.google.de/books?id=LMM6AAAAcAAJ [accessed 22 Jun. 2016].

Brayshaw T.C. 1976. Catkin bearing Plants of British Columbia. British Columbia Provincial Museum, Victoria [Occasional Papers of the British Columbia Provincial Museum 18].

Brickell C.D., Alexander C., David J.C., Hetterscheid W.L.A., Leslie A.C., Malecot V., Jin X. \& Cubey J.J. 2009. International Code of nomenclature for cultivated plants. Scripta Horticulturae 10: 1-184.

Britten J. 1912. The history of Aiton's 'Hortus Kewensis'. Journal of Botany, British and Foreign 50 (Suppl.): 1-16.

Britton N.L. \& Brown A. 1913. An Illustrated Flora of the Northern United States ed. 2. Vol. 1. Charles Scribner's sons, New York. https://doi.org/10.5962/bhl.title.55504

Brookshaw G. 1817. Pomona Britannica. T. Bensley, London.

Browicz K. 1972. Corylaceae. In: Rechinger K.H. (ed.) Flora Iranica. Vol. 97. Akademische Druckund Verlagsanstalt, Graz.

Bunyard E.A. 1920. Cob nuts and filberts. Journal of the Royal Horticultural Society n.s. 45: 225-232.

Burchardt T.H.O. 1833. XIII. Beiträge zur Geschichte der Kultur der Haselnüsse und ihrer Sorten. Verhandlungen des Vereins zu Beförderung des Gartenbaues in den Königlich Preußischen Staaten 9: 93-145.

Burchardt T.H.O. 1841. XXI. Fortsetzung der Vermerkungen über die Kultur der Haselnüsse und ihrer Sorten. Verhandlungen des Vereins zu Beförderung des Gartenbaues in den Königlich Preußischen Staaten 15: 80-86.

Burkill I.H. 1899. Cupuliferae: Corylae. The Journal of the Linnean Society. Botany 26: 501-505.

Camerarius the Younger J. 1588. Hortus Medicus et Philosophicus, in quo plurimarum stirpium breves descriptiones... continentur. S. Feyerabend, H. Dack, et P. Fischer, Frankfurt.

Camus A. 1930 [“1929”]. Sur le Corylus yunnanensis (Franchet) A. Camus. Bulletin du Muséum National d'Histoire Naturelle ser. 2 1: 438-439.

Camus A., Gillot F.X. \& Malinvaud L.J.E. 1905. Société pour l'étude de la Flora franco-helvétique 1904. Bulletin de l'Herbier Boissier ser. 2 5: 973-977.

Candolle A.L.P.P. de 1864. Prodromus Systematis Naturalis Regni Vegetabilis. Vol. 16 (2): 1-160. Treuttel \& Würtz, Paris. 
Chang C.-S., Chang G.-S. \& Qin H.-N. 2004. A multivariate morphometric study on Corylus sieboldiana complex (Betulaceae) in China, Korea, and Japan. Acta Phytotaxonomica Sinica 42: 222-235.

Cordus V. 1561. Annotationes in Pedacii Dioscoridis Anazarbei De medica materia libros V. Iosias Rihelius, Argentoratum [Strasbourg]. https://doi.org/10.5962/bhl.title.8036

Dailledouze J.P. \& Dailledouze J. 1828. Catalogue des Arbres, Arbrisseaux, Arbustes, et Plantes de Pleine Terre. Barbezat et Delarue, Geneva.

Dippel L. 1891 [“1892"]. Handbuch der Laubholzkunde. Vol. 2. P. Parey, Berlin. https://doi.org/10.5962/bhl.title. 12978

Dochnahl F.J. 1860. Der sichere Führer in der Obstkunde auf botanisch-pomologischem Wege, oder Systematische Beschreibung aller Obstsorten. Vol. 4. W. Schmid, Nürnberg.

Dodoens R. 1557. Histoire des Plantes. Iean Loë, Anvers.

Döll J.C. 1843. Rheinische Flora. Heinrich Ludwig Brönner, Frankfurt am Main, Germany.

Du Roi J.P. 1771. Die Harbkesche wilde Baumzucht. Vol. 1. Fürstliche Waisenhaus-Buchhandlung, Braunschweig.

Editorial Board of the Flora Sichuanica 2012. Flora Sichuanica. Vol. 21. Sichuan Publishing Group, Chengdu, China.

Ehrhart F. 1780. Versuch eines Verzeichnisses der um Hannover wild wachsenden Pflanzen. Hannoverisches Magazin 18: 209-240.

Erdoğan V. 1999. Genetic Relationships among Hazelnut (Corylus) Species. PhD thesis, Oregon State University, Corvallis, U.S.A.

Erdoğan V. \& Mehlenbacher S.E. 2000. Interspecific hybridization in hazelnut (Corylus). Journal of the American Society for Horticultural Science 125 (4): 489-497.

Fairbairn A., Kulakoğlu F. \& Atici L. 2014. Archaeobotanical evidence for trade in hazelnut (Corylus sp.) at Middle Bronze Age Kültepe (c. 1950-1830 b.c.), Kayseri Province, Turkey. Vegetation History and Archaeobotany 23 (2): 167-174. https://doi.org/10.1007/s00334-013-0403-5

FAOstat 2013. FAOstat 3. Available from http://faostat3.fao.org [accessed 22 Jun. 2016].

Farwell O.A. 1915. Contributions to the botany of Michigan no.14. Report of the Michigan Academy of Science 17: 167-182.

Fernald M.L. 1932. Corylus americana, forma missouriensis. Rhodora 34: 96.

Fernald M.L. 1936. A Smooth-husked Hazel. Rhodora 38: 76.

Fine P.V.A., Misiewicz T.M., Chavez A.S. \& Cuthrell R.Q. 2013. Population genetic structure of California Hazelnut, an important source for people in Quiroste Valley in the Late Holocene. California Archaeology 5 (2) 353-370. https://doi.org/10.1179/1947461X13Z.00000000019

Fingerhut C.A. 1829. Einiges zur deutschen Flora. Linnaea 4: 372-386.

Forest F., Savolainen V., Chase M.W., Lupia R., Bruneau A. \& Crane P.R. 2005. Teasing apart molecular versus fossil-based error estimates when dating phylogenetic trees: a case study in the birch Family (Betulaceae). Systematic Botany 30 (1): 118-133. https://doi.org/10.1600/0363644053661850

Franchet A. 1899. Plantarum Sinensium Ecologe Tertia. Journal de Botanique 13: 197-208.

Franz W.R. 1992. Corylus avellana L. var. laciniata Kirchn. — eine seltene Mutante der Hasel in Klagenfurt (Kärnten). Wulfenia 1: 20-27. 
Fries E.M. 1845. Summa Vegetabilium Scandinaviae. Vol. 1. A. Bonnier, Stockholm and Leipzig.

Fuchs L. 1542. De Historia Stirpium Commentarii Insignes. Isingrin, Basel.

Furlow J.J. 1997. Betulaceae. In: Flora of North America Editorial Committee (ed.) Flora of North America: North of Mexico. Vol. 3. Oxford University Press, New York.

Gajić M. \& Korać M. 1979. Nova forma leske. Glasnik Prirodnaučkog Museja u Beogradu. Serija B Biološke nauke. Belgrade [Bulletin du Museum d'Histoire Naturelle Belgrade. Serie B. Sciences Biologiques. Belgrade] 33: 59-60.

Godet C.H. 1839. Énumération des végétaux vasculaires qui croissent dans le canton de Neuchatel. Mémoires de la Société des sciences naturelles de Neuchâtel 2: I-IX, 1-55.

Godet C.H. 1853. Flore du Jura. Vol. 2. Librairie de Jean-Pierre Michaud, Neuchâtel.

Goeschke F. 1887. Die Haselnuss. P. Parey, Berlin.

Gökirmak T., Mehlenbacher S.A. \& Bassil N.V. 2009. Characterization of European hazelnut (Corylus avellana) cultivars using SSR markers. Genetic Resources and Crop Evolution 56: 147-172. https://doi.org/10.1007/s10722-008-9352-8

Govaerts R. \& Frodin D.G. 1998. World Checklist and Bibliography of Fagales (Betulaceae, Corylaceae, Fagaceae and Ticodendraceae). The Royal Botanic Gardens Kew, England.

Greuter W. \& Holstein N. 2016. Dochnahl's pomological books and their relevance for botanical nomenclature. Taxon 65: 337-342. https://doi.org/10.12705/652.10

Grimm G.W. \& Renner S.S. 2013. Harvesting Betulaceae sequences from GenBank to generate a new chronogram for the family. Botanical Journal of the Linnean Society 172: 465-477. https://doi.org/10.1111/boj.12065

Gronovius J.F. 1762. Flora Virginica ed. 2. Lugdunum batavorum [Leiden]. https://doi.org/10.5962/bhl.title.60264

Hayata B. 1917. General Index to the Flora of Formosa as recorded in all literature up to the publication of Icones Plantarum Formosanarum. Taiwan Sotokufu Minseibu Shokusankyoku, Taihoku. https://doi.org/10.5962/bhl.title.11087

Henriksson J. 1915. Om Corylus avellana. Botaniska Notiser 1915 (5): 237-247.

Henriksson J. 1918. Om Corylus avellana. Botaniska Notiser 1918 (6): 237-247.

Henriksson J. 1923. Om Corylus avellana. Botaniska Notiser 1923 (3): 280-284.

Henriksson J. 1927. Om Corylus avellana. Botaniska Notiser 1927 (2): 156-160.

Henriksson J. 1930. Om Corylus avellana. Botaniska Notiser 1930 (2): 149-153.

Henriksson J. 1931. Om Corylus avellana. Botaniska Notiser 1931 (2): 213-218.

Hermann P. 1687. Horti Academici Lugduno-batavi Catalogus. C. Boutesteyn, Leiden. https://doi.org/10.5962/bhl.title.98142

Hickel R. 1928. Un nouveau Corylus de Chine: Corylus papyracea. Bulletin de la Société Dendrologique de France 68: 93-94.

Holst D. 2010. Hazelnut economy of early Holocene hunter-gatherers: a case study from Mesolithic Duvensee, northern Germany. Journal of Archaeological Science 37: 2871-2880. https://doi.org/10.1016/j.jas.2010.06.028 
Holstein N. \& Greuter W. 2016. (19) Proposal to add Der sichere Führer in der Obstkunde vol. 1-4 by F.J. Dochnahl to the list of "Suppressed Works". Taxon 65: 401. https://doi.org/10.12705/652.31

Holstein N. \& Weigend M. 2016a. An annotated checklist and lectotypification of Ostryopsis Decne. (Betulaceae), with notes on the numbering system in the collections of P.J.M. Delavay. Phytotaxa 282 (3): 235-238. https://doi.org/10.11646/phytotaxa.282.3.9

Holstein N. \& Weigend M. 2016b. (2458) Proposal to reject the name Corylus virginiana (Betulaceae). Taxon 65 (4): 888 . https://doi.org/10.12705/654.23

Holstein N. \& Weigend M. 2017. No taxon left behind? - a critical taxonomic checklist of Carpinus and Ostrya (Coryloideae, Betulaceae). European Journal of Taxonomy 375: 1-52. https://doi.org/10.5852/ejt.2017.375

Hu H.H. 1937. Notulae Systematicae ad Florem Sinensium. Bulletin of the Fan Memorial Institute of Biology, Botany 8: 31-46.

Hu H.H. 1948. Notulae Systematicae ad Floram Sinensem XI. Bulletin of the Fan Memorial Institute of Biology n.s. 1 (2): 141-152.

Hu H.H. 1972. 中国高等植物图鉴 [Iconographia Cormophytorum Sinicorum]. Vol. 1. Science Press, Beijing.

Ives C., Sathuvalli V.R., Colburn B.C. \& Mehlenbacher S.A. 2014. Mapping the incompatibility and style color loci in two hazelnut progenies. HortScience 49 (3): 250-253.

Jacquemont V. 1844. Voyage dans l'Inde. Vol. 4 (3). Firmin Didot frères, Paris.

Jarvis C.E., Barrie F.R., Allan D.M. \& Reveal J.L. 1993. A List of Linnaean Generic Names and their Types. Koeltz Scientific Books, Koenigstein.

Jepson W.L. 1923. A Manual of the Flowering Plants of California: 129-384. Sather Gate Bookshop, Berkeley, CA, USA.

Keightley D.N. 1983. The Origins of Chinese Civilization. University of California Press, Berkeley, Los Angeles, London.

Kemularia-Nathadze L.M. 1933. Два новьіх растения из западной Грузии [Two new plants from western Georgia]. Trudy Tbilisskogo Botaniceskogo Instituta 1: 111-115.

Kemularia-Nathadze L.M. 1938. Древовидная лещина в Грузии и ее Гибриды [The treehazel in Georgia and its hybrids]. Trudy Tbilisskogo Botaniceskogo Instituta 6: 11-17.

Kemularia-Nathadze L.M. 1978. Taxa nova Corylacearum e Georgia (Caucuasus). Zametki po Sistematike i Geografii Rastenii. Tiflis 35: 3-6.

Ketskhoveli N.N., Makashvili A.K. \& Sosnovski D.I. 1975. Flora Gruzii. Vol. 3. Meznireba, Tbilisi.

Kitagawa M. 1979. Neolineamenta Florae Manshuricae. J. Cramer, Vaduz.

Koch K. 1849. Beiträge zu einer Flora des Orients. Linnaea 22: 177-338.

Koch K. 1867. Die Deutschen Obstgehölze. F. Enke, Stuttgart. Available from https://archive.org/details/diedeutschenobs00kochgoog [accessed 22 Jun. 2016].

Koch K. 1873. Dendrologie; Bäume, Sträucher und Halbsträucher, welche in Mittel- und Nord- Europa im Freien kultivirt werden. Vol. 2. F. Enke, Erlangen. https://doi.org/10.5962/bhl.title.20459

Koidzumi G. 1913. Spicilegium Betulacearum Japonicarum novarum vel minus cognitarum. The Botanical Magazine [Tokyo] 27: 143-149. 
Komarov V.L. 1929. Corylus brevituba sp. nova. Izvestija Glavnogo Botaniceskogo Sada SSSR [Bulletin du Jardin (Botanique) Principal de l'URSS] 28: 219.

Korallova V.V. \& Panova L.A. 1971. Пыльца покрытосеменных растений из олигоценовых отложений Причерноморской впадины [Pollen of angiosperms from the Oligocene deposits of the Black Sea depression]. Геология и рудоносность Юга Украины [Geology and ore content of the South of Ukraine] 4: 19-31.

Kosenko I.S. 2002. Ліщини в Україні [Hazels in Ukraine]. Академперіодика, Київ [Kiev].

Kosenko I.S. \& Opalko A.I. 2007. Інтродукція рослин на початку XXI століття: Досягнення i перспективи (До 120-річчяз дня народження академіка М.І.Вавилова) [Plant introduction in the beginning of the XXI century: Achievements and perspectives (To the $120^{\text {th }}$ anniversary of the birthday of Academician M.I. Vavilov)]. Матеріали Міжнародної наукової конференції (2-4 жовтня 2007 р.) [Materials of the International Scientific Conference (October 2-4, 2007)]: 70-74.

Krüssmann G. 1960. Handbuch der Laubgehölze. Vol. 1. Paul Parey, Berlin.

Lamarck J.B.A.P. de. 1796-1797. Tableau Encyclopédique et Méthodique des Trois Règnes de la Nature. Botanique. Vol. 2. Pancoucke, Paris.

Langhe J.E. de 1973. Formes aberrantes de plantes indigènes en Belgique. Bulletin de la Société Royale de Botanique de Belgique 106: 69-73.

La Tourrette M.A.L. Claret de \& Rozier F. 1787. Démonstrations Élémentaires de Botanique. Vol. 3. Bruyset frères, Lyon. Available from https://books.google.de/books?id=sU87AAAAcAAJ [accessed 22 Jun. 2016].

Ledebour C.F. von 1841. Commentarius in J.G. Gmelini Floram. Denkschriften der KöniglichBaierischen Botanischen Gesellschaft in Regensburg 3: 43-138.

Ledebour C.F. von 1850 [“1850-1851”]. Flora Rossica. Vol. 3 (2): 493-684. E. Schweizerbart, Stuttgart.

Lejeune A.L.S. \& Courtois R. 1836. Compendium Florae Belgicae. Vol. 3. A. Remacle, Verviers. https://doi.org/10.5962/bhl.title.44830

Li J.-H. 2008. Sequences of low-copy nuclear gene support the monophyly of Ostrya and paraphyly of Carpinus (Betulaceae). Journal of Systematics and Evolution 46 (3): 333-340. https://doi.org/10.3724/SP.J.1002.2008.08026

Li P.-C. \& Cheng S.-X. 1979. Betulaceae. In: Kuang K.-Z. \& Li P.-C. (eds.) Flora Republicae Popularis Sinicae 21: 44-137. Science Press, Beijing.

Li P.-C. \& Skvortsov A.K. 1999. Betulaceae. In: Wu Z.Y. \& Raven P.H. (eds.) Flora of China 4: 286-301. Science Press, Beijing, and Missouri Botanical Garden Press, St. Louis.

Liang W.J. 1988. 关于川榛分类地位的商榷及新变种关于川榛分类地位的商榷及新变种 [Discussion on the taxonomic status of the Sichuan Hazel and discussion on new varieties]. Bulletin of Botanical Research. Harbin 8 (4): 115-117.

Lindberg H. 1944. Schedae Operis quod inscribitur Plantae Finlandiae Exsiccatae e Museo Botanico Universitatis Helsingforsiensis distributae. Fasc. XXI-XLII. Helsingforsiæ [Helsinki].

Lindley J. 1829. The Cosford nut. The Pomological Magazine 2: 55, pl. 55.

Lin Q., Sun Q., Sun M. \& Li H.L. 2007. Lectotypifications of twenty-eight names of Chinese taxa in Angiospermae. Acta Botanica Boreali-Occidentalia Sinica 27 (6): 1247-1255.

Linnaeus C. 1737. Hortus Cliffordianus. Amsterdam. https://doi.org/10.5962/bhl.title.690 
HOLSTEIN N. et al., Taxonomic checklist of Corylus

Linnaeus C. 1753. Species Plantarum. Laurentius Salvius, Stockholm. https://doi.org/10.5962/bhl.title.669

Liu L. \& Chen X. 2012. The Archaeology of China: From the Late Paleolithic to the Early Bronze Age. Cambridge University Press, New York.

Liu Q.X. \& Zhang C.M. 1990. A new species of the Corylus from China. Bulletin of Botanical Research. Harbin 10 (1): 35-37.

Living J. \& Braithwaite R. 2013. The Peter Collinson Heritage. Available from http://www.mhps.org.uk/collinson-garden.asp [accessed 22 Mar. 2016].

Loddiges W. 1836. Catalogue of Plants ed. 16. W. Wilson, London.

Loudon J.C. 1829. Encyclopedia of Plants. Longman, Rees, Orme, Brown and Green, London. https://doi.org/10.5962/bhl.title.37645

Loudon J.C. 1838. Arboretum et Fruticetum Britannicum. Vol. 3. Longman, Orme, Brown, Green, and Longmans, London. https://doi.org/10.5962/bhl.title.37723

Ludwig C.F. 1783. Die Neuere Wilde Baumzucht. Müller, Leipzig. Available from http://www.mdz-nbn-resolving.de/urn/resolver.pl?urn=urn:nbn:de:bvb:12-bsb10293944-2 [accessed 22 Mar. 2016].

Marie-Victorin J.L. \& Rousseau J. 1940. Nouvelles entités de la flore phanérogamique du Canada oriental. Contributions de l'Institut Botanique de l'Université de Montréal 36: 5-74.

Marshall H. 1785. Arbustrum Americanum. J. Crukshank, Philadelphia.

Maximowicz C.J. 1881. Diagnoses plantarum novarum asiaticarum IV. Bulletin de l'Académie Impériale des Sciences de St.-Pétersbourg 27: 425-560.

Maximowicz C.J. \& Ruprecht F.J. 1856. Die ersten botanischen Nachrichten über das Amurland. Bulletin de la Classe Physico-Mathématique de l'Académie Impériale des Sciences de Saint-Pétersbourg 15 (89):120-144.

McNeill J., Barrie F.R., Buck W.R., Demoulin V., Greuter W., Hawksworth D.L., Herendeen P.S., Knapp S., Marhold K., Prado J., Prud'homme van Reine W.F., Smith G.F., Wiersema J.H. \& Turland N.J. 2012. International Code of Nomenclature for Algae, Fungi, and Plants (Melbourne Code). Koeltz Scientific Books, Koenigstein.

Mehlenbacher S.A. \& Smith D.C. 1995. Inheritance of the cutleaf trait in hazelnut. HortScience 30 (3): 611-612.

Miller P. 1759. The Gardeners Dictionary ed. 7. John Rivington et al., London.

Miller P. 1768. The Gardeners Dictionary ed. 8. John Rivington et al., London. https://doi.org/10.5962/bhl.title.541

Miyabe K. \& Kudo Y. 1934. Flora of Hokkaido and Saghalien IV: Dicotyledonae archichlamydeae Saururaceae - Polygonaceae. Journal of the Faculty of Agriculture, Hokkaido University 26 (4): 389528.

Mouillefert P. 1891-1898. Traité des Arbres \& Arbrisseaux. Vol. 2. Librairie des sciences naturelles Paul Klincksieck, Paris. Available from http://gallica.bnf.fr/ark:/12148/bpt6k441427m [accessed 22 Mar. 2016].

Müller L. 1861. Theodor Heinrich Otto Burchardt. Pomologische Monatszeitschrift 7: 65-66.

Münchhausen O. von. 1754. Erzählung der vornehmsten bey uns wild wachsenden Bäume. Hannover 'sche Gelehrte Anzeigen 3(61) 889-936. 
Münchhausen O. von 1768. Der Hausvater. Vol. 3 (3). Förster, Hanover.

Münchhausen O. von 1770. Der Hausvater. Vol. 5. Förster, Hanover.

Murr J. 1931. Neue Beiträge zur Flora der Umgebung von Innsbruck und des übrigen Nordtirols. Veröffentlichungen des Tiroler Landesmuseums Ferdinandeum 11: 39-80.

Murray A.E. 1982. Notae Spermatophytae. Kalmia 12: 18-27.

Nakai T. 1914. Plantae novae Coreanae et Japonicae I. Repertorium Specierum Novarum Regni Vegetabilis 13: 243-250.

Nakai T. 1915. Flora Sylvatica Koreana. Vol. 2. Government of Chosen, Keijo.

Nakai T. 1939. Notulae ad Plantas Asiae Orientalis (IX). Journal of Japanese Botany 15 (9): 523-541.

Nestel H. 1869. Avis. Nestel's Rosengarten 2: 15-22.

Noisette L. 1825. Manuel Complet du Jardinier, Maraicher, Pépiniériste, Botaniste, Fleuriste et Paysagiste. Vol. 2. Rousselon, Paris. https://doi.org/10.5962/bhl.title.44049

Ohwi J. 1965. Flora of Japan [in English]. Smithsonian Institution, Washington, DC.

Palmer E.J. \& Steyermark J.A. 1935. An annotated catalogue of the flowering plants of Missouri. Annals of the Missouri Botanical Garden 22: 375-758.

Petrov V.A. 1936. La septième avelinier de la flore de l'URSS. Byulleten'Moskovskogo Obshchestva Ispytatelei Prirody, Otdel Biologicheskii 45 (2): 119-128.

Petzold E.C.A. \& Kirchner G. 1864. Arboretum Muscaviense. W. Opetz, Gotha. Available from https://books.google.de/books/about?id=a5UCAAAAYAAJ [accessed 22 Jun. 2017].

Pliny the Elder 77-79. Naturalis Historia 15 (24). Available from http://www.perseus.tufts.edu/hopper/text?doc=urn:cts:latinLit:phi0978.phi001.perseus-eng1:15.24 [accessed 22 Jun. 2017].

Pluskal F.S. 1852. Ueber Corylus serenyiana. Oesterreichisches Botanisches Wochenblatt 2: 394-395.

Pluskal F.S. 1853. Phanerogamen-Flora der Gegend von Lomnitz in Mähren, nebst den bisher aufgefundenen Varietäten. Verhandlungen des Zoologisch-Botanischen Vereins in Wien 3 (2): 1-26

Poiteau P.A. 1846. Pomologie Française Recueil des Plus Beaux Fruits Cultivés en France. Vol. 4. Langlois and Leclercq, Paris.

Poiteau P.A. \& Turpin P.J.F. 1835. Traité des Arbres Fruitiers. Vol. 6. F.G. Levrault, Strasbourg.

Rea J. 1665. Flora. Thomas Clarke, London. https://doi.org/10.5962/bhl.title.50878

Regel E. von 1857. Vegetations-Skizzen des Amurlandes, gesammelt von dem Reisenden des Kaiserl. Botanischen Garten zu St. Petersburg, Hrn. Maximowicz; nebst Bemerkungen über die von demselben eingesendeten Bäume und Sträucher. Bulletin de la Classe Physico-Mathématique de l'Académie Impériale des Sciences de Saint-Pétersbourg 15 (14-15): 211-238.

Rehder A. 1926. New species, varieties and combinations from the herbarium and the collections of the Arnold Arboretum. Journal of the Arnold Arboretum 7 (2): 145-150.

Rehder A. 1927. Manual of Cultivated Trees and Shrubs Hardy in North America. MacMillan, New York.

Rehder A. 1949. Bibliography of Cultivated Trees and Shrubs Hardy in the Cooler Temperate Regions of the Northern Hemisphere. The Arnold Arboretum of Harvard University, Jamaica Plain, MA, USA. 
Reichenbach H.G.L. 1850. Icones Florae Germanicae et Helveticae. Vol. 12. Fridericus Hofmeister, Lipsiae [Leipzig]. http://dx.doi.org/10.5962/bhl.title.6353

Reveal J.L. \& Pringle J.S. 1993. Taxonomic Botany and Floristics. In: Flora of North America Editorial Committee (ed.) Flora of North America: North of Mexico 1: 157-192. Oxford University Press, New York.

Risso A. 1826. Histoire Naturelle des Principales Productions de l'Europe Méridionale et particulièrement de Celles des Environs de Nice et des Alpes Maritimes. Vol. 2. F.-G. Levrault, Strasbourg. https://doi.org/10.5962/bhl.title.58984

Rivera Núñez D., Obón de Castro C., Rios Ruiz S., Selma Ferrández C., Méndez Colmenero F., Verde López A. \& Cano Trigueros F. 1997. Las Variedades Tradicionales de Frutales de la Cuenca del Río Segura. Catálogo Etnobotánico (1): Frutos Secos, Oleaginosos, Frutales de Hueso, Almendros y Frutales de Pepita. University of Murcia, Murcia.

Rose J.N. 1895. Notes upon Corylus rostrata and C. californica. Garden \& Forest 8: 263.

Salisbury R.A. 1796. Prodromus Stirpium in Horto ad Chapel Allerton Vigentium. London. https://doi.org/10.5962/bhl.title.427

Sargent C.S. 1916. Plantae Wilsonianae. Vol. 2. The University press, Cambridge. https://doi.org/10.5962/bhl.title.191

Săvulescu T. 1952. Flora Republicii Populare Române. Vol. 1. Academiei republicii populare Române, București.

Schneider C.K. 1904 ["1906"]. Illustriertes Handbuch der Laubholzkunde. Vol. 1. G. Fischer, Jena. https://doi.org/10.5962/bhl.title.194

Schneider C.K. 1912. Illustriertes Handbuch der Laubholzkunde. Vol. 2. G. Fischer, Jena. https://doi.org/10.5962/bhl.title.194

Sharp A.J. \& James L.E. 1951. Relationships between the Floras of California and Southeastern United States. Natural History Museum of Stanford University, Stanford [Contributions from the Dudley Herbarium of Stanford University 4].

Siebold P.F. von 1844. Kruidkundige naamlijst van oud en nieuw ingevoerde Japansche en Chineesche planten. In: Siebold P.F. von, Annuaire de la Société Royale pour l'Encouragement de l'Horticulture dans les Pays-Bas: 23-39. H.W. Hazenberg \& Comp., Leiden.

Siebold P.F. von \& Zuccharini J.G. 1846. Florae japonicae familiae naturales, adjectis generum et specierum exemplis selectis. sectio prima. plantae dicotyledoneae polypetalae. Abhandlungen der Mathematisch-Physikalischen Klasse der Königlich Bayerischen Akademie der Wissenschaften 4 (3): 109-240.

Spach É. 1841. Notes sur les Corylus. Annales des Sciences naturelles, seconde série - Botanique 16: 98-108. Available from https://biodiversitylibrary.org/page/36215646 [accessed 6 Dec. 2017].

Späth F.L. 1883. Baumschule. Haupt-Preis-Verzeichniss 1883. Berlin, Germany

Späth F.L. 1885. Gehölz-Neuheiten. Dr. Neubert's Deutsches Garten-Magazin 38: 20-22.

Stafleu F.A. \& Cowan R.S. 1976-1988. Taxonomic Literature II. Bohn, Scheltema \& Holkeman, Dr. W. Junk b.v., Publishers, Utrecht, Antwerpen, The Hague, Netherlands, Boston, USA.

Steudel E.G. von. 1840. Nomenclator Botanicus ed. 2. Vol. 2. J. G. Cottae, Stuttgart; Tübingen. https://doi.org/10.5962/bhl.title. 655 
Strelin G.G. 1788. Realwörterbuch für Kameralisten und Oekonomen. Vol. 4. K.G. Beck, Nördlingen. Available from http://www.mdz-nbn-resolving.de/urn/resolver.pl?urn=urn:nbn:de:bvb:12-bsb10313074-2 [accessed 22 Jun. 2017].

Tessier A.-H., Thouin A. \& Bosc L.A.G. 1821. Encyclopédie Méthodique, Agriculture. Vol. 7. A.P. Agasse, Paris. Available from http://gallica.bnf.fr/ark:/12148/bpt6k58317044 [accessed 27 Jun. 2016].

The Benedictine Monks of St. Augustine's Abbey, Ramsgate. 1921. The Book of Saints. A \& C. Black, London. Available from https://archive.org/details/bookofsaintsdict00stau [accessed 27 Jun. 2016].

The Plant List 2013. Version 1.1. Available from http://www.theplantlist.org/ [accessed 1 Jul. 2015].

Thomas O. 1876. Guide Pratique de l'Amateur de Fruits. E. Réau, Nancy.

Thompson M.M. 1985. Linkage of the incompatibility locus and red pigmentation genes in hazelnut. Journal of Heredity 76: 119-122.

Thompson M.M., Lagerstedt B.H. \& Mehlenbacher S.A. 1996. Hazelnuts. In: Janick J. \& Moore J.N. (eds) Fruit Breeding 3: 125-184. John Wiley \& Sons, New York, New York. https://doi.org/10.1093/oxfordjournals.jhered.a110035

Trautvetter E.R. von 1844. Plantarum Imagines et Descriptiones Floram Russicam Illustrantes. Vol. 1. E. Schweizerbart, Stuttgart. https://doi.org/10.5962/bhl.title.6362

Tung S.L. 1981. 东北桦木科植物的研究 [Study on Betulaceae of North-Eastern China]. Bulletin of Botanical Research. Harbin 1 (1-2): 123-151.

Tutin T.G. \& Walters S.M. 1993. Corylaceae. In: Tutin T.G., Burges N.A., Chater A.O., Edmondson J.R., Heywood V.H., Moore D.M., Valentine D.H., Walters S.M. \& Webb D.A. (eds) Flora Europaea 1: 70-71. Cambridge University Press, Cambridge.

Wallich N. 1830. Plantae Asiaticae Rariores. Vol. 1. Treuttel and Würtz, London. https://doi.org/10.5962/bhl.title.468

Walter T. 1788. Flora Caroliniana. J. Fraser, London. https://doi.org/10.5962/bhl.title.9458

Wangenheim F.A.J. von 1787. Beytrag zur Teutschen Holzgerechten Forstwissenschaft. Johann Christian Dieterich, Göttingen.

Ward D.B. 2007. Thomas Walter Typification Project IV: neotypes and epitypes for 43 Walter names, of genera A through C. Journal of the Botanical Research Institute of Texas 1 (2): 1091-1100.

Watson P.W. 1823-1825. Dendrologia Britannica. Vol. 2. London.

WCSP 2016. World Checklist of Selected Plant Families. Available from http://apps.kew.org/wcsp/ [accessed 27 Jun. 2016].

Whitcher I.N. \& Wen J. 2001. Phylogeny and biogeography of Corylus (Betulaceae): inferences from ITS sequences. Systematic Botany 26: 283-298. https://doi.org/10.1043/0363-6445-26.2.283

Willdenow C.L. von 1805. Species Plantarum. Vol. 4. G.C. Nauk, Berlin. https://doi.org/10.5962/bhl.title.727

Willdenow C.L. von 1809. Enumeratio Plantarum Horti Regii Berolinensis. Realschulbuchhandlung, Berlin. Available from http://bibdigital.rjb.csic.es/ing/Libro.php?Libro=1684 [accessed 27 Jun. 2016].

Wilson K.L. 2017. Report of the General Committee: 18. Taxon 66 (3): 742-744. https://doi.org/10.12705/663.15 
Winkler H.J.P. 1904. Betulaceae. In: Engler H.G.A. (ed.) Das Pflanzenreich. IV 61 (Heft 19). Wilhelm Engelmann, Berlin. Available from http://biodiversitylibrary.org/item/17309 [accessed 27 Jun. 2016].

Zapałowicz H. 1908. Conspectus Florae Galiciae Criticus. Vol. 2. Academiae litterarum Cracoviensis, Kraków.

Zernov A.S. 2002. Определитель сосудистых растений севера Российского Причерноморья [Manual of vascular plants in the north of the Russian Black Sea Coast]. KMK, Moscow.

Zhao L. \& Chen D.Y. 1988. Flora Liaoningica 1: 1988. Liaoning Science \& Technology Publishing, Shenyang.

Zohary D., Hopf M. \& Weiss E. 2012. Domestication of Plants in the Old World: the Origin and Spread of Domesticated Plants in Southwest Asia, Europe, and the Mediterranean Basin. Oxford University Press, Oxford.

Zuccarini J.G. 1833. Ueber den gegenwärtigen Zustand des königlichen Herbariums. Die Bayerischen Annalen 1833 (14): 101-103.

Manuscript received: 13 October 2016

Manuscript accepted: 2 March 2017

Published on: 28 February 2018

Topic editor: Koen Martens

Desk editor: Alejandro Quintanar

Printed versions of all papers are also deposited in the libraries of the institutes that are members of the EJT consortium: Muséum national d'Histoire naturelle, Paris, France; Botanic Garden Meise, Belgium; Royal Museum for Central Africa, Tervuren, Belgium; Natural History Museum, London, United Kingdom; Royal Belgian Institute of Natural Sciences, Brussels, Belgium; Natural History Museum of Denmark, Copenhagen, Denmark; Naturalis Biodiversity Center, Leiden, the Netherlands; Museo Nacional de Ciencias Naturales-CSIC, Madrid, Spain; Real Jardín Botánico de Madrid CSIC, Madrid, Spain. 